\title{
Structural analysis and biomedical potential of novel salicyloyloxy estrane derivatives synthesized by microwave irradiation
}

\author{
Olivera R. Klisuricí ${ }^{1} \cdot$ Mihály Szécsi $^{2} \cdot$ Evgenija A. Djurendić $^{3} \cdot$ Szabó Nikoletta $^{2}$. \\ Bianka Edina Herman ${ }^{2}$ - Suzana S. Jovanović Šanta ${ }^{3}$ Sanja V. Dojčinović Vujašković ${ }^{3}$. \\ Andrea R. Nikolić ${ }^{3}$ Ksenija J. Pavlović ${ }^{3}$ Jovana J. Ajdukovićc ${ }^{3}$ - Aleksandar M. Oklješa ${ }^{3}$ \\ Edward T. Petrii ${ }^{4}$ Vesna V. Kojić ${ }^{5}$ Marija N. Sakač ${ }^{3} \cdot$ Katarina M. Penov Gaši $^{3}$
}

Received: 26 June 2015/ Accepted: 7 September 2015/Published online: 19 September 2015

(C) Springer Science+Business Media New York 2015

\begin{abstract}
New estrane salicyloyloxy or D-homo derivatives were synthesized under microwave (MW) or conventional heating from estrane precursors and methyl salicylate. The MW technique provides advantages regarding product yield and reaction time, and represents a more environmentally friendly approach than conventional heating. Considering the biomedical potential of estrane compounds, we evaluated the antioxidant activity and cytotoxicity of synthesized estrane derivatives in a series of in vitro tests, as well as their $3 \beta$-hydroxysteroid dehydrogenase $/ \Delta^{5} \rightarrow \Delta^{4}$ isomerase (3ßHSD) and $17 \beta$-hydroxysteroid dehydrogenase types 1,2 and 3 (17ßHSD1, $17 \beta$ HSD 2 and $17 \beta$ HSD3) inhibition potentials. In DPPH tests, 3-methoxyestra-1,3,5(10)-trien-17 $\beta$-yl salicylate displayed antioxidant potential, while all compounds exhibited $\mathrm{OH}$ radical neutralization activity. 3-Oxoestr-4-en$17 \beta$-yl salicylate showed strong cytotoxicity against MDAMB-231 breast cancer cells, while 17-oxoestra-1,3,5(10)trien-3-yl salicylate, estra-1,3,5(10)-triene-3,17ß-diyl
\end{abstract}

Olivera R. Klisurić

olivia@uns.ac.rs

1 Department of Physics, Faculty of Sciences, University of Novi Sad, Trg Dositeja Obradovića 4, 21000 Novi Sad, Serbia

2 1st Department of Medicine, University of Szeged, Korányi fasor 8-10, 6720 Szeged, Hungary

3 Department of Chemistry, Biochemistry and Environmental Protection, Faculty of Sciences, University of Novi Sad, Trg Dositeja Obradovića 3, 21000 Novi Sad, Serbia

4 Department of Biology and Ecology, Faculty of Sciences, University of Novi Sad, Trg Dositeja Obradovića 4, 21000 Novi Sad, Serbia

5 Oncology Institute of Vojvodina, Put Dr Goldmana 4, 21204 Sremska Kamenica, Serbia 3-benzoate 17-salicylate and 3-benzyloxy-17-salicyloyloxy-16,17-secoestra-1,3,5(10)-triene-16-nitrile showed the strongest inhibition of $\mathrm{PC}-3$ prostate cancer cell growth. 3 -Hydroxyestra-1,3,5(10)-trien-17 $\beta$-yl salicylate was the best inhibitor of $17 \beta \mathrm{HSD} 2$, suggesting potential use in treating pathological conditions associated with estrogen depletion. For 3-methoxyestra-1,3,5(10)-trien-17 $\beta$-yl salicylate and 3-oxoestr-4-en-17 $\beta$-yl salicylate, X-ray crystal structure analysis and molecular energy optimization were performed to define their conformations and energy minima. Very good overlap in the region of the steroidal nucleus was observed for the molecular structures of each analyzed molecule in the crystalline state and after energy optimization, while conformer analysis indicates conformational flexibility in the form of rotation around the $\mathrm{C} 17 \cdots \mathrm{O} 2$ bond. Structural geometry analysis for these compounds shows that the region of ring $\mathrm{A}$ in steroids, and especially the $\mathrm{C} 3$ atom functional group, is important structural features concerning antiproliferative activity against MDA-MB-231 cells.

Keywords Estrane salicylic acid derivatives . Microwave-assisted (MW) synthesis - Biomedical potential $\cdot$ X-ray structural analysis $\cdot$ Energy optimization

\section{Introduction}

Hormone-stimulated cell proliferation, which increases the number of cell divisions and the opportunity for genetic mutations, is associated with carcinogenesis in hormonerelated cancers. In target tissues, steroid hormones are interconverted between their potent, high-affinity forms and inactive, low-affinity forms for their respective receptors. Enzymes partly responsible for these interconversions are 


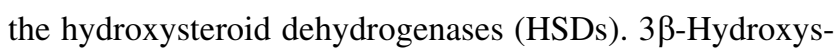
teroid dehydrogenase $/ \Delta^{5} \rightarrow \Delta^{4}$ isomerase (3ßHSD) is present in many tissues [1]. This enzyme catalyzes both conversion of the hydroxyl group on carbon 3 (C3) to a keto group and double bond isomerization during the conversion of pregnenolone to progesterone or other substrates. Since $3 \beta$-HSD is involved in the biosynthesis of nearly all steroid hormones, inhibition of $3 \beta-H S D$ could represent a potential target for the treatment of hormone dependent cancers. $17 \beta$ Hydroxysteroid dehydrogenases catalyze either oxidation of hydroxyl groups or reduction of keto groups at steroid position $\mathrm{C} 17$ [2, 3]. 17ß-Hydroxysteroid dehydrogenase type $1(17 \beta H S D 1)$ activates the less active estrone to $17 \beta-$ estradiol, a potent ligand for estrogen receptors; thus, inhibitors of this enzyme are highly interesting potential therapeutic agents for the control of estrogen-dependent diseases such as endometriosis, as well as breast and ovarian cancers. $17 \beta$ HSD1 is inhibited by some estradiol derivatives [4-7]. $17 \beta \mathrm{HSD} 2$ catalyzes the reverse process (17 $\beta$-estradiol to estrone); thus, inhibitors of this isoform could enable better regulation of the levels of active estrogens. Therapeutically, $17 \beta$ HSD2 inhibitors could be used in the treatment of osteoporosis. Some estrane derivatives proved to be 17ßHSD 2 inhibitors. [8, 9]. 17 $\beta \mathrm{HSD} 3$, synthesized in testis, activates androst-4-ene-3,17-dione into testosterone. Thus, $17 \beta$ HSD 3 inhibitors could be therapeutics for the treatment of prostate cancer or similar diseases. Some steroidal compounds expressed good inhibitory potential for this isoform [10].

Estrane compounds decrease tumor cell proliferation in vitro by different mechanisms, enabling alternative approaches to cancer therapy [11-17]. Some estrane derivatives affect tumor cells via estrogen receptors, while others induce cell death or cell cycle arrest, or prevent cancer progression by scavenging free radicals.

Estrogen hormones have well-known effects on female reproductive tissues, but also display beneficial effects in many other tissues, largely due to their antioxidant potential. In addition, among the family of steroidal molecules, estrogens have shown the most potential for preventing neuronal cell death caused by increased oxidative damage [18-20].

On the other hand, some phenolic substances act as powerful antioxidants and/or cytotoxic agents. Salicylic acid derivatives are phenolic compounds exhibiting such activities [21-28].

Combining the structural characteristics of both estrane compounds and salicylic acid, we recently reported some new biomedically potent steroidal derivatives [29]. In the present study, we present the synthesis, structural analysis and biological activity of some newly synthesized salicyloyloxy estrane derivatives. Since the relationship between oxidative stress and carcinogenesis is well established [30], we examined the effectiveness of newly synthesized salicyloyloxy estrane derivatives at free radical scavenging and inhibition of tumor cell proliferation, as well as their inhibitory potential against $3 \beta \mathrm{HSD}, 17 \beta \mathrm{HSD} 1,17 \beta \mathrm{HSD} 2$ and 17ßHSD3.

Herein we report X-ray crystal structures of 3-methoxyestra-1,3,5(10)-trien-17 $\beta$-yl salicylate (11) and 3-oxoestr4-en-17 $\beta$-yl salicylate (14), as well as their molecular energy optimization. Because of their interesting biological activities, we also compared the structural features of new crystal structures (11 and 14) with several previously reported structures [28].

\section{Experimental}

\section{Chemical synthesis}

\section{General}

Infrared spectra (wave numbers in $\mathrm{cm}^{-1}$ ) were recorded on a Nexus 670 FT-IR spectrometer. Nuclear magnetic resonance (NMR) spectra were recorded on a Bruker AC 250 apparatus operating at $250 \mathrm{MHz}$ (proton) and $62.9 \mathrm{MHz}$ (carbon), using standard Bruker software, with tetramethylsilane as the internal standard. Chemical shifts are given in ppm ( $\delta$-scale); coupling constants $(J)$ are given in Hz. High-resolution mass spectra (TOF) were recorded on a 6210 Time-of-Flight LC/MS Agilent Technologies (ESI+) instrument. Absorbances of reaction mixtures in free radical scavenging tests were recorded on a CECIL CE2021 spectrophotometer. The microwave reactor was a monomode system (Microwave Synthesis System-Discover Bench Mate from CEM) with focused waves. Melting points were determined using a Büchi SMP 20 apparatus and are uncorrected. Organic solutions were dried over $\mathrm{Na}_{2} \mathrm{SO}_{4}$ and evaporated on a rotary evaporator under reduced pressure. Column chromatography was performed on Merck grade 60 silica gel $(0.063-0.2 \mathrm{~mm})$.

General procedure for the preparation of compounds 7-14

Microwave-assisted (MW) synthesis A mixture consisting of methyl salicylate $(18 \mathrm{mmol})$, the corresponding steroidal compound $(1 \mathrm{mmol})$ and sodium $(3 \mathrm{mmol})$ was heated to $110^{\circ} \mathrm{C}$. When reaction with sodium was completed (5-10 $\mathrm{min})$, toluene $(3 \mathrm{ml})$ was added and then the mixture was irradiated for $30 \mathrm{~min}$ at $130-200{ }^{\circ} \mathrm{C}$, using a $200-\mathrm{W}$ microwave source. After cooling the reaction mixture to room temperature, water $(100 \mathrm{~mL})$ and $\mathrm{HCl}(1: 1$, to $\mathrm{pH} 7)$ were added and crude product was extracted with dichloromethane $(3 \times 50 \mathrm{~mL})$. The organic phase was 
dried and evaporated, resulting in an oily product. Chromatographic separation of crude product on a silica gel column (toluene-EtOAc, 9:1 for 7; petroleum ether-acetone, 20:1 for 8 and 9; toluene-EtOAc, 27:1 for 10; petroleum ether-acetone, 10:1 for 11; toluene-EtOAc, 24:1 for 12 and 13; toluene-EtOAc, 24:1 for 14) gave the pure products 7-9 and 11-14.

Conventionally heated synthesis A mixture consisting of methyl salicylate $(18 \mathrm{mmol})$, the corresponding steroidal compound ( $1 \mathrm{mmol})$, sodium $(3 \mathrm{mmol})$ and toluene $(3 \mathrm{~mL})$ was refluxed for 5.5-24 h, depending on the substrate. After reaction completion, the reaction mixture was cooled to room temperature, water $(100 \mathrm{~mL})$ and $\mathrm{HCl}(1: 1$, to $\mathrm{pH}$ $7)$ were added, and crude product was extracted with dichloromethane $(3 \times 50 \mathrm{~mL})$. The extract was dried and solvent was evaporated to dryness. Pure compounds $\mathbf{7 , 8}$ and 10-14 were obtained from crude mixture after chromatography on a silica gel column (toluene-EtOAc, 18:1 for 7; $n$-hexane-acetone, 19:1 for 8; $n$-hexane-acetone, 45:1 for 10; $n$-hexane-acetone, 15:1 for 11; petroleum ether-acetone, 9:1 for $\mathbf{1 2}$ and 13; toluene-EtOAc, 12:1 for 14).

3-Hydroxyestra-1,3,5(10)-trien-17 $\beta$-yl salicylate (7) Light yellow crystals, mp $81-84{ }^{\circ} \mathrm{C}$ from acetone-hexane [[29], mp $\left.81-84{ }^{\circ} \mathrm{C}\right]$.

17-Oxoestra-1,3,5(10)-trien-3-yl salicylate (8) White crystals, mp $230{ }^{\circ} \mathrm{C}$ from $n$-hexane-acetone. IR (KBr): 3205, 2933, 2871, 1737, 1686, 1615, 1583, 1301, 1247, 1208, 1157, 1068, 759, 699. ${ }^{1} \mathrm{H}$ NMR $\left(\mathrm{CDCl}_{3}\right): 0.92$ (s, 3H, $\mathrm{H}-18$ ); 6.93-8.07 (group of signals, 7H, H-Ar); 10.55 (s, $1 \mathrm{H}, \mathrm{OH}$ phenolic group from salicyloyl residue). ${ }^{13} \mathrm{C}$ NMR $\left(\mathrm{CDCl}_{3}\right)$ : 13.69 (C-18); 21.46; 25.62; 26.17; 29.30; 31.40; $35.72 ; 37.81 ; 44.01 ; 47.79 ; 50.24 ; 111.72 ; 117.67 ; 118.65$; $119.25 ; 121.47 ; 126.51 ; 130.20 ; 136.32 ; 137.89 ; 138.21$; 147.81; 162.02; 169.09 ( $\mathrm{C}=\mathrm{O}$ from salicyloyl group); 220.60 (C-17). HRMS (TOF) m/z: $\mathrm{C}_{25} \mathrm{H}_{26} \mathrm{O}_{4}[\mathrm{M}+\mathrm{H}]^{+}$ calculated: 391.19039, found: 391.18963 .

Estrone 3-methyl ether (9) White crystals, mp $170{ }^{\circ} \mathrm{C}$ from hexane-dichloromethane [[31], mp $\left.169^{\circ} \mathrm{C}\right]$.

Estra-1,3,5(10)-triene-3,17 $\beta$-diyl 3-benzoate 17-salicylate (10) White crystals, mp $190-194{ }^{\circ} \mathrm{C}$ from $n$-hexanedichloromethane. IR (KBr): 3148, 2930, 1730, 1669, 1614, $1485,1303,1248,1213,1158,1063,763,704 .{ }^{1} \mathrm{H}$ NMR $\left(\mathrm{CDCl}_{3}\right): 1.03 \quad(\mathrm{~s}, \quad 3 \mathrm{H}, \mathrm{H}-18) ; 4.98 \quad(\mathrm{t}, \quad 1 \mathrm{H}, \mathrm{H}-17$, $J=8.26 \mathrm{~Hz}$ ); 6.89-8.25 (group of signals, $12 \mathrm{H}, \mathrm{H}-\mathrm{Ar}$ ); $10.96(\mathrm{~s}, 1 \mathrm{H}, \mathrm{OH}$ phenolic group from salicyloyl residue). ${ }^{13} \mathrm{C}$ NMR $\left(\mathrm{CDCl}_{3}\right)$ : 12.28 (C-18); 23.32; 25.96; 26.97; $27.64 ; 29.46 ; 36.85 ; 38.08 ; 43.24 ; 43.90 ; 49.66 ; 83.62$ (C$17) ; 112.74 ; 117.51 ; 118.69 ; 119.03 ; 121.60 ; 126.44$;
$128.46 ; 129.57 ; 129.76 ; 130.07 ; 133.44 ; 135.51 ; 137.67$; $138.27 ; 148.64 ; 161.57(\mathrm{C}-2) ; 165.38$ (C=O from benzoate); 170.08 ( $\mathrm{C}=\mathrm{O}$ from salicyloyl group). HRMS (TOF) $\mathrm{m} / \mathrm{z}$ : $\mathrm{C}_{32} \mathrm{H}_{32} \mathrm{O}_{5} \quad[\mathrm{M}+\mathrm{H}]^{+}$calculated: 497.23225, found: 497.23250.

3-Methoxyestra-1,3,5(10)-trien-17 $\beta$-yl salicylate (11) White crystals, mp $190-194{ }^{\circ} \mathrm{C}$ from $n$-hexane-dichloromethane. IR (KBr): 3139, 2934, 1669, 1613, 1583, 1500, 1325, 1252, 1159, 1142, 1094, 1034, 995, 759, 737, 704. ${ }^{1} \mathrm{H}$ NMR $\left(\mathrm{CDCl}_{3}\right): 0.98$ (s, 3H, H-18); $3.78\left(\mathrm{~s}, 3 \mathrm{H}, \mathrm{OCH}_{3}\right) ; 4.95(\mathrm{t}, 1 \mathrm{H}$, $\mathrm{H}-17, J=7.62 \mathrm{~Hz}$ ); $6.64-7.88$ (group of signals, $7 \mathrm{H}, \mathrm{H}-$ $\mathrm{Ar}) ; 10.91(\mathrm{~s}, 1 \mathrm{H}, \mathrm{OH}$ phenolic group from salicyloyl residue). ${ }^{13} \mathrm{C}$ NMR $\left(\mathrm{CDCl}_{3}\right)$ : 12.35 (C-18); 23.37; 26.17; 27.22; $27.70 ; 29.76 ; 36.94 ; 38.55 ; 43.35 ; 43.75 ; 49.69 ; 55.18$; $83.74 ; 111.47 ; 112.83 ; 113.78 ; 117.55 ; 119.06 ; 126.35$; $129.82 ; 132.31 ; 135.53 ; 137.84 ; 157.46 ; 161.61 ; 170.15$ $(\mathrm{C}=\mathrm{O})$. HRMS (TOF) $\mathrm{m} / \mathrm{z}: \mathrm{C}_{26} \mathrm{H}_{30} \mathrm{O}_{4}[\mathrm{M}-\mathrm{H}]^{-}$calculated: 405.20713, found: 405.20783 .

3-Benzyloxy-17-salicyloyloxy-16,17-secoestra-1,3,5(10)-triene-16-nitrile (12) Yellow oil IR (film): 3187, 3033, 2929, 2243, 1676, 1613, 1500, 1299, 1249, 1158, 1089, 758, 735, 699. ${ }^{1} \mathrm{H}$ NMR $\left(\mathrm{CDCl}_{3}\right): 1.09$ (s, 3H, H-18); $4.06(\mathrm{~d}, 1 \mathrm{H}$, $\mathrm{H}-17 \mathrm{a}, J=11.50 \mathrm{~Hz}), 4.33(\mathrm{~d}, 1 \mathrm{H}, \mathrm{H}-17 \mathrm{~b}, J=11.52 \mathrm{~Hz}$ ); 5.03 (s, $2 \mathrm{H}, \mathrm{CH}_{2}$ from $\mathrm{Bn}$ ); 6.73-7.85 (group of signals, $\mathrm{H}-$ $\mathrm{Ar}) ; 10.71$ (s, 1H, OH phenolic group from salicyloyl residue). ${ }^{13} \mathrm{C}$ NMR $\left(\mathrm{CDCl}_{3}\right)$ : 15.92 (C-15), 16.24 (C-18); 25.94; $27.02 ; 29.93 ; 36.25 ; 38.03 ; 39.37 ; 42.18 ; 42.87 ; 69.90\left(\mathrm{CH}_{2}\right.$ from $\mathrm{Bn}) ; 71.77$ (C-17); 112.08; 112.72; 114.38; 117.81; $119.10(\mathrm{C} \equiv \mathrm{N}) ; 119.38 ; 126.41 ; 127.43 ; 127.88 ; 128.54$; $129.50 ; 131.57 ; 136.05 ; 137.12 ; 137.42 ; 156.95$ (C-3); 161.79; 169.86 ( $\mathrm{C}=\mathrm{O}$ from salicyloyl group); HRMS (TOF) $\mathrm{m} / \mathrm{z}: \mathrm{C}_{32} \mathrm{H}_{33} \mathrm{O}_{4} \mathrm{~N}[\mathrm{M}+\mathrm{H}]^{+}$calculated: 496.24824 , found 496.24763.

3-Benzyloxy-17-oxa-D-homoestra-1,3,5(10)-trien-16-one (13) White crystals, $\mathrm{mp} 167-169^{\circ} \mathrm{C}$ from $n$-hexanedichloromethane [32, mp $\left.162{ }^{\circ} \mathrm{C}\right]$.

3-Oxoestr-4-en-17 $\beta$-yl salicylate (14) White crystals, mp 213-214 ${ }^{\circ} \mathrm{C}$ from $n$-hexane-dichloromethane. IR (KBr): $3117,2945,2860,1663,1614,1583,1485,1302,1252$, 1214, 1157, 1093, 795. ${ }^{1} \mathrm{H}$ NMR $\left(\mathrm{CDCl}_{3}\right): 0.99(\mathrm{~s}, 3 \mathrm{H}$, $\mathrm{H}-18$ ); 4.85 (t, 1H, H-17, $J=8.27 \mathrm{~Hz}$ ), 5.83 (s, 1H, H-4); 6.84-7.85 (group of signals, $4 \mathrm{H}, \mathrm{H}-\mathrm{Ar}$ ); 10.87 (s, $1 \mathrm{H}, \mathrm{OH}$ phenolic group from salicyloyl residue). ${ }^{13} \mathrm{C}$ NMR $\left(\mathrm{CDCl}_{3}\right): 12.22$ (C-18); 23.31; 25.82; 26.46; 27.45; 30.43; $35.26 ; 36.40 ; 36.52 ; 39.97 ; 42.32 ; 42.97 ; 49.18 ; 49.29$; 83.41 (C-17); $112.61\left(\mathrm{C}-1^{\prime}\right) ; 117.46\left(\mathrm{C}-3^{\prime}\right) ; 118.98\left({\left.\mathrm{C}-6^{\prime}\right)}^{\prime}\right.$; 124.57 (C-4); $129.67 ; 135.49\left(\mathrm{C}-4^{\prime}\right) ; 161.49\left(\mathrm{C}-2^{\prime}\right) ; 166.29$ (C-5); 169.97 (C=O from salicyloyl group); 199.85 (C-3). HRMS (TOF) m/z: $\mathrm{C}_{25} \mathrm{H}_{30} \mathrm{O}_{4} \quad[\mathrm{M}+\mathrm{H}]^{+}$calculated: 395.22169, found: 395.22172 . 


\section{Biological tests}

\section{DPPH radical scavenging assay}

The free radical scavenging capacity (RSC) of selected salicyloyloxy estrane derivatives (7, 11 and 14) and reference compounds (commercial synthetic anti-oxidants: 3,5-di-tert-butyl-4-hydroxytoluene/BHT Aldrich, Germany, and 3-tert-butyl-4-hydroxyanisole/BHA Fluka, Germany), estradiol, compound $\mathbf{5}$ and methyl salicylate were evaluated by measuring their ability to neutralize 2,2diphenyl-1-picrylhydrazyl (DPPH) and hydroxyl (HO) radicals.

The DPPH assay was performed as described [29]. Different aliquots $(0.1-2.0 \mathrm{~mL})$ of $0.01 \mathrm{M}$ sample solution (compounds in dichloromethane) were added to DPPH in methanol (90 $\mu \mathrm{M}, 1 \mathrm{~mL}$; Sigma, St. Louis, MO) and diluted with 95 vol\% of methanol to a final volume of $4 \mathrm{~mL}$. The same reaction mixture without test compounds was used as a control. Absorbance of the reaction mixtures ( $\left.A_{\text {sample }}\right)$ and control $\left(A_{\text {control }}\right)$ was recorded at $515 \mathrm{~nm}$ after $1 \mathrm{~h}$. For each sample, three replicates were recorded. The percentage of DPPH radical scavenging capacity (DPPH RSC) was calculated using the following equation:

$\operatorname{RSC}(\%)=100 \times\left(A_{\text {control }}-A_{\text {sample }} / A_{\text {control }}\right)$

$\mathrm{IC}_{50}$ values (the concentration of test compound in the reaction mixture which causes $50 \%$ of RSC) were determined by linear regression analysis from RSC values obtained.

\section{Hydroxyl radical scavenging assay}

The hydroxyl radical scavenging capacity (HO RSC) of selected compounds was evaluated by measuring the degradation of 2-deoxy-D-ribose (Aldrich, Germany) during reaction with $\mathrm{OH}$ radicals, generated in situ in Fenton's reaction [29]. Different aliquots $(0.005-0.5 \mathrm{~mL})$ of a sample solution in dichloromethane were added to test tubes (final concentration in the range of $0.01-8 \mathrm{mM}$, each containing $0.1 \mathrm{~mL}$ of $5 \mathrm{mM} \mathrm{H} \mathrm{H}_{2}, 0.1 \mathrm{~mL}$ of $10 \mathrm{mM}$ $\mathrm{FeSO}_{4}, 0.1 \mathrm{~mL}$ of $0.05 \mathrm{M}$ 2-deoxy-D-ribose, and $0.067 \mathrm{M}$ $\mathrm{KH}_{2} \mathrm{PO}_{4}-\mathrm{K}_{2} \mathrm{HPO}_{4}$ buffer of $\mathrm{pH} 7.4$ to a final volume of $3 \mathrm{~mL}$ ). The same reaction mixture without sample was used as control. After an incubation period of $1 \mathrm{~h}$ at $37^{\circ} \mathrm{C}$, $2 \mathrm{~mL}$ of TBA reagent $\left(10.4 \mathrm{~mL}\right.$ of $60 \mathrm{vol} \% \mathrm{HClO}_{4}, 3 \mathrm{~g}$ of TBA, and $120 \mathrm{~g}$ of trichloroacetic acid (Sigma, St. Louis, MO, USA) ) and $0.2 \mathrm{~mL}$ of $0.1 \mathrm{M}$ EDTA (Sigma, St. Louis, MO, USA) were added to the reaction mixture and the tubes were heated at $100{ }^{\circ} \mathrm{C}$ for $20 \mathrm{~min}$. After cooling, absorbance of the reaction mixtures and control was recorded at $532 \mathrm{~nm}$. The percentage of HO RSC was calculated using Eq. (1). Three replicates were recorded for each sample. Estradiol, methyl salicylate, BHT and BHA were used as reference compounds. $\mathrm{IC}_{50}$ values (the concentration at which $50 \%$ of $\mathrm{HO}$ is neutralized) were determined by linear regression analysis from obtained RSC values.

\section{Cytotoxicity}

The cytotoxicity of synthesised compounds $\mathbf{7}$ and 9-14 was evaluated by the colorimetric sulforhodamine B (SRB) assay [29, 33]. The chemotherapy drug doxorubicin (DOX) was used as a control. Three human cancerous cell lines and one normal cell line were used in this study: estrogen receptor positive human breast adenocarcinoma $(\mathrm{ER}+$, MCF-7), estrogen receptor negative human breast adenocarcinoma (ER-, MDA-MB-231), human prostate cancer (PC-3) and normal fetal lung fibroblasts (MRC-5). Cells were grown in Dulbecco's modified Eagle's medium with $4.5 \%$ glucose. Media were supplemented with $10 \%$ of fetal calf serum and antibiotics $\left(100 \mathrm{IU} \mathrm{mL}^{-1}\right.$ of penicillin and $100 \mu \mathrm{g} \mathrm{mL}^{-1}$ of streptomycin; ICN Galenika). All cells were cultured in flasks (Costar, $25 \mathrm{~cm}^{2}$ ) at $37{ }^{\circ} \mathrm{C}$ in an atmosphere of $100 \%$ humidity and $5 \% \mathrm{CO}_{2}$ in an incubator. Only viable cells were used in the assay. Viability was determined by dye exclusion assay with trypan blue.

Cytotoxicity was evaluated by the colourimetric sulforhodamine B (SRB) assay [33]. Briefly, a single-cell suspension $\left(5 \times 10^{3}\right.$ cells $)$ was plated into 96-well microtitre plates (Costar, flat bottom). The plates were pre-incubated at $37{ }^{\circ} \mathrm{C}$ in a $5 \% \mathrm{CO}_{2}$ incubator for $24 \mathrm{~h}$. The substances tested (final concentrations ranging from $10^{-8}$ to $10^{-4} \mathrm{M}$ ) were transferred into all wells except for controls. After the incubation period $\left(48 \mathrm{~h} / 37{ }^{\circ} \mathrm{C} / 5 \% \mathrm{CO}_{2}\right)$, the cytotoxicity assay was carried out as follows: $50 \mu \mathrm{L}$ of $80 \%$ trichloroacetic acid (TCA) was added to all wells; $1 \mathrm{~h}$ later, plates were washed with distilled water, and $75 \mu \mathrm{L}$ of $0.4 \% \mathrm{SRB}$ was added to all wells; after 30-min incubation, the plates were washed with citric acid $(1 \%)$ and dried at room temperature. Finally, $200 \mu \mathrm{L}$ of $10 \mathrm{mM}$ Tris ( $\mathrm{pH}$ 10.5) base was added to all wells. Absorbance was measured using a microplate reader. Wells without cells, containing only complete medium, served as blanks. Cytotoxicity was calculated according to the following equation:

$\mathrm{CI}(\%)=\left(1-A_{\text {sample }} / A_{\text {control }}\right) \times 100$

Three independent experiments were conducted in quadruplicate for each concentration of test compound. The $\mathrm{IC}_{50}$ (dose of a compound that inhibits cell growth by $50 \%$ ) of test compounds was determined by median effect analysis. 
Determination of $3 \beta H S D, 17 \beta H S D 1,17 \beta H S D 2$ and $17 \beta H S D 3$ activities and their inhibition

Inhibitory effects exerted on steroidogenic enzymes by the newly synthesized compounds 7, 10-12 and 14 were investigated with in vitro radio-labeled substrate incubations (Table 1). Our previously published methods for

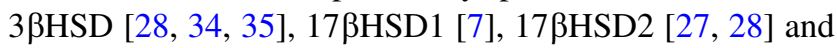
$17 \beta$ HSD3 [28] were used with minor modifications. During procedures, tissue preparations serving as enzyme sources were incubated with $1 \mu \mathrm{M}\left[{ }^{14} \mathrm{C}\right]$-labeled substrate steroids in the presence of $0.1 \mathrm{mM}$ coenzymes at $37^{\circ} \mathrm{C}$. Buffer medium consisted of 0.1 M HEPES ( $\mathrm{pH}$ 7.3), 1 mM EDTA and $1 \mathrm{mM}$ dithiothreitol. The appropriate substrate was added in $10 \mu \mathrm{L}$ of $25 \mathrm{v} / \mathrm{v} \%$ propylene glycol in HEPES buffer solution, whereas test compounds were applied in $10 \mu \mathrm{L}$ of dimethyl sulfoxide solution. In a final reaction volume of $200-\mu \mathrm{L}$ incubation medium, these organic solvents did not reduce enzyme activity substantially. After incubation, enzymatic reactions were stopped by addition of EtOAc and cooling. Unlabeled carriers of the substrate and product steroids were added, and samples were then extracted. Substrates and products were separated by TLC on Kieselgel-G (Merck Si 254 F) layers (0.25 mm thick) with the solvent system dichloromethane-diisopropyl etherEtOAc $(75: 15: 10 \mathrm{v} / \mathrm{v})$, and UV spots were used to trace the separated steroids. Spots were cut out and radioactivity was measured by means of liquid scintillation counting. Test compounds were applied at $50 \mu \mathrm{M}$ concentration, and controls without test substances were also prepared in every series. At least two experiments were performed with each test compound. $\mathrm{IC}_{50}$ values were determined for more potent inhibitors. In this case, conversion was measured at five or six different concentrations of the test compound between 0.1 and $50 \mu \mathrm{M}$.

\section{X-ray crystallographic analysis of compounds 11 and 14}

Diffraction data for compounds $\mathbf{1 1}$ and $\mathbf{1 4}$ were collected at room temperature on an Oxford Diffraction (Agilent Technologies) Gemini S diffractometer using the program package CrysAlis CCD [36] with graphite-monochromated
MoK $\alpha$ radiation $(\lambda=0.7107 \AA)$. Data reductions were performed with the program package CrysAlis RED [36]. Space group determinations were based on analysis of the Laue class and systematically absent reflections. Structures were solved by direct methods using SHELXT [37] for 11 and SIR92 [38] for 14. Structures were refined by fullmatrix least squares procedures on $F^{2}$ using SHELXL2014/6 program [37]. For both compounds, non-hydrogen atoms were refined anisotropically and $\mathrm{C}-\mathrm{H}$ hydrogen atoms were included on calculated positions riding on their attached atoms with fixed distances of $0.93 \AA(\mathrm{CH}$; some hydrogen atoms from $\mathrm{CH}$ groups were identified using difference electron density maps), $0.97 \AA\left(\mathrm{CH}_{2}\right)$ and $0.96 \AA\left(\mathrm{CH}_{3}\right)$. At the final stage of refinement, $\mathrm{H}$ atoms from the hydroxyl group were identified by difference electron density maps and isotropically refined.

In the absence of significant anomalous scattering effects, Friedel pairs for both compounds were merged. The absolute configuration of 11 and 14 can be assumed without risk based on the absolute configuration of the starting material, considering that the synthetic transformations carried out do not affect the chirality in the naturally occurring steroid framework, although the refined Flack parameters $x=0.3(6)$ for 11 and $x=0.3(5)$ for 14 [39] are not definitive.

All calculations were performed using PARST [40] and PLATON [41], as implemented in the WINGX [42] system of programs. The crystal data and refinement parameters are summarized in Table 2.

\section{Results and discussion}

Steroidal derivatives 7-14 were synthesized by reaction of methyl salicylate with compounds 1-6 (Table 3). Reactions were performed by MW irradiation and conventional heating, in the presence of sodium and toluene as solvent. Substrates 1, 4 and $\mathbf{6}$ gave corresponding salicyloyl esters 7, 11 and 14 by transesterification reaction under conventional heating or MW irradiation. However, substrates 2, 3 and $\mathbf{5}$ showed different reactivity. Namely, by conventional heating substrate $\mathbf{2}$ was converted into the corresponding salicyloyl ester 8, but in MW-assisted reaction conditions,

Table 1 Description of radiosubstrate enzyme incubation methods used for inhibition tests

\begin{tabular}{lllll}
\hline Enzyme & $3 \beta$ HSD & $17 \beta$ HSD1 & $17 \beta$ HSD2 & $17 \beta$ HSD3 \\
\hline Enzyme source & Rat testicular homogenate & Human placental cytosol & Rat liver microsomes & Rat testicular homogenate \\
Substrate & Dehydroepi-androsterone & Estrone & Testosterone & Androst-4-ene-3,17-dione \\
Product & Androst-4-ene-3,17-dione & $17 \beta$-Estradiol & Androst-4-ene-3,17-dione & Testosterone \\
Coenzyme & NAD & NADH & NAD & NADPH \\
Incubation time $(\min )$ & 20 & 2.5 & 20 & 20 \\
\hline
\end{tabular}


Table 2 Experimental details: crystallographic data and refinement parameters

\begin{tabular}{|c|c|c|}
\hline & 11 & 14 \\
\hline Chemical formula & $\mathrm{C}_{26} \mathrm{H}_{30} \mathrm{O}_{4}$ & $\mathrm{C}_{25} \mathrm{H}_{30} \mathrm{O}_{4}$ \\
\hline$M_{\mathrm{r}}$ & 406.50 & 394.49 \\
\hline Crystal system, space group & Monoclinic, $P 2_{1}$ & Orthorhombic, $P 2{ }_{1} 2{ }_{1} 2_{1}$ \\
\hline$a, b, c(\AA)$ & 8.7591(7), 7.3572(6), 16.8520(13) & 7.1646(3), 11.5003(5), 25.5462(10) \\
\hline$\beta\left(^{\circ}\right)$ & $90.759(6)$ & - \\
\hline$V\left(\AA^{3}\right)$ & $1085.89(15)$ & $2104.88(15)$ \\
\hline$Z$ & 2 & 4 \\
\hline$\mu\left(\mathrm{mm}^{-1}\right)$ & 0.08 & 0.08 \\
\hline Crystal size $(\mathrm{mm})$ & $0.57 \times 0.21 \times 0.15$ & $0.41 \times 0.36 \times 0.15$ \\
\hline Diffractometer & $\begin{array}{l}\text { Gemini S; Agilent Technologies } \\
\text { (Oxford Diffraction) diffractometer }\end{array}$ & \\
\hline \multirow[t]{3}{*}{ Absorption correction } & Analytical [50] & Multi-scan \\
\hline & CrysAlis RED [36] & CrysAlis RED [36] \\
\hline & $\begin{array}{l}\text { Numeric absorption correction using } \\
\text { a multifaceted crystal model }\end{array}$ & $\begin{array}{l}\text { Empirical absorption correction using } \\
\text { spherical harmonics, implemented in } \\
\text { SCALE3 ABSPACK scaling algorithm }\end{array}$ \\
\hline$T_{\min }, T_{\max }$ & $0.958,0.989$ & $0.949,1.000$ \\
\hline $\begin{array}{l}\text { No. of measured, independent and } \\
\text { observed }[I>2 \sigma(I)] \text { reflections }\end{array}$ & $5183,3332,1915$ & $5894,3288,2232$ \\
\hline$R_{\text {int }}$ & 0.018 & 0.017 \\
\hline$R\left[F^{2}>2 \sigma\left(F^{2}\right)\right], w R\left(F^{2}\right), S$ & $0.033,0.072,0.85$ & $0.035,0.069,0.90$ \\
\hline No. of parameters & 293 & 279 \\
\hline No. of restraints & 1 & 0 \\
\hline $\mathrm{H}$-atom treatment & \multicolumn{2}{|c|}{$\mathrm{H}$ atoms treated by a mixture of independent and constrained refinement } \\
\hline$\Delta \rho_{\max }, \Delta \rho_{\min }\left(\mathrm{e} \AA^{-3}\right)$ & $0.09,-0.12$ & $0.11,-0.10$ \\
\hline
\end{tabular}

in addition to esterification reaction, methylation of the phenol moiety of compound $\mathbf{2}$ occurred predominantly, leading to methylether $\mathbf{9}$. In the case of substrate $\mathbf{3}$, conventional methods afforded a mixture of salicyloyl esters 7 and 10, while the MW method provided only ester 7. In both methods, the C3-benzoyloxy group of compound $\mathbf{3}$ was converted, partially or completely, into a C3-hydroxyl group. Lactone 13, previously reported [32], was obtained in addition to salicyloyl ester $\mathbf{1 2}$ from D-seco substrate $\mathbf{5}$ by both conventional and MW-assisted methods.

In order to compare the efficiency of the two reaction conditions, we compared reaction time and yields of newly synthesized compounds (Table 3) for both MW-assisted and conventional syntheses.

During transesterification of methyl salicylate with estradiol 1 under conventional heating (13 h), the salicyloyl ester 7 was obtained at $36 \%$ yield [29]. MW-assisted transesterification (30 min) afforded the desired compound 7 at higher yield (50\%), while the reaction time was shortened 26-fold compared to conventional heating. Conventional heating of estrone (2) with methyl salicylate gave 3-salicyloyloxy derivative $\mathbf{8}$ at $32 \%$ yield. MW irradiation of the mixture of methyl salicylate and estrone
$(4 \times 30 \mathrm{~min})$ resulted in the synthesis of estrone 3-methyl ether $(9,17 \%)$ as the main product and 3-salicyloyloxy derivative 8 as a by-product $(2 \%)$. Starting from 3-benzoyloxy-17 $\beta$-hydroxyestra-1,3,5(10)-triene (3), 17 $\beta$-salicyloyloxy derivative $\mathbf{1 0}(17.5 \%)$ and compound 7 $(10.8 \%)$ were obtained using conventional heating, while transesterification of methyl salicylate with compound $\mathbf{3}$, performed by MW irradiation for $30 \mathrm{~min}$, afforded a complex mixture from which only compound 7 could be isolated $(18.4 \%)$. In the reaction of estradiol 3-methyl ether (4) with methyl salicylate, 3-methoxy 17 $\beta$-salicyloyloxy derivative $\mathbf{1 1}$ was obtained. This reaction lasted $5.5 \mathrm{~h}$ under conventional heating, while the same reaction was completed in only $30 \mathrm{~min}$ using MW irradiation. Moreover, the MW irradiation method led to an almost twofold increase in yield of compound 11(68.5\%).

D-Secocyanoalcohol 5 [43] reacted with methyl salicylate by conventional heating $(13 \mathrm{~h})$, yielding 17-salicyloyloxy derivative 12 (12.6\%) and D-homo-lactone $\mathbf{1 3}$ as by-product $(3.8 \%)$. In our earlier paper [32], lactone 13 was synthesized in high yield $(57 \%)$ by the treatment of the starting secocyanoalcohol $\mathbf{5}$ with catalytic amounts of $p$-toluenesulfonic acid in benzene. MW irradiation of the 
Table 3 The structures of starting and product compounds and reaction conditions for both MW-assisted and conventional synthesis

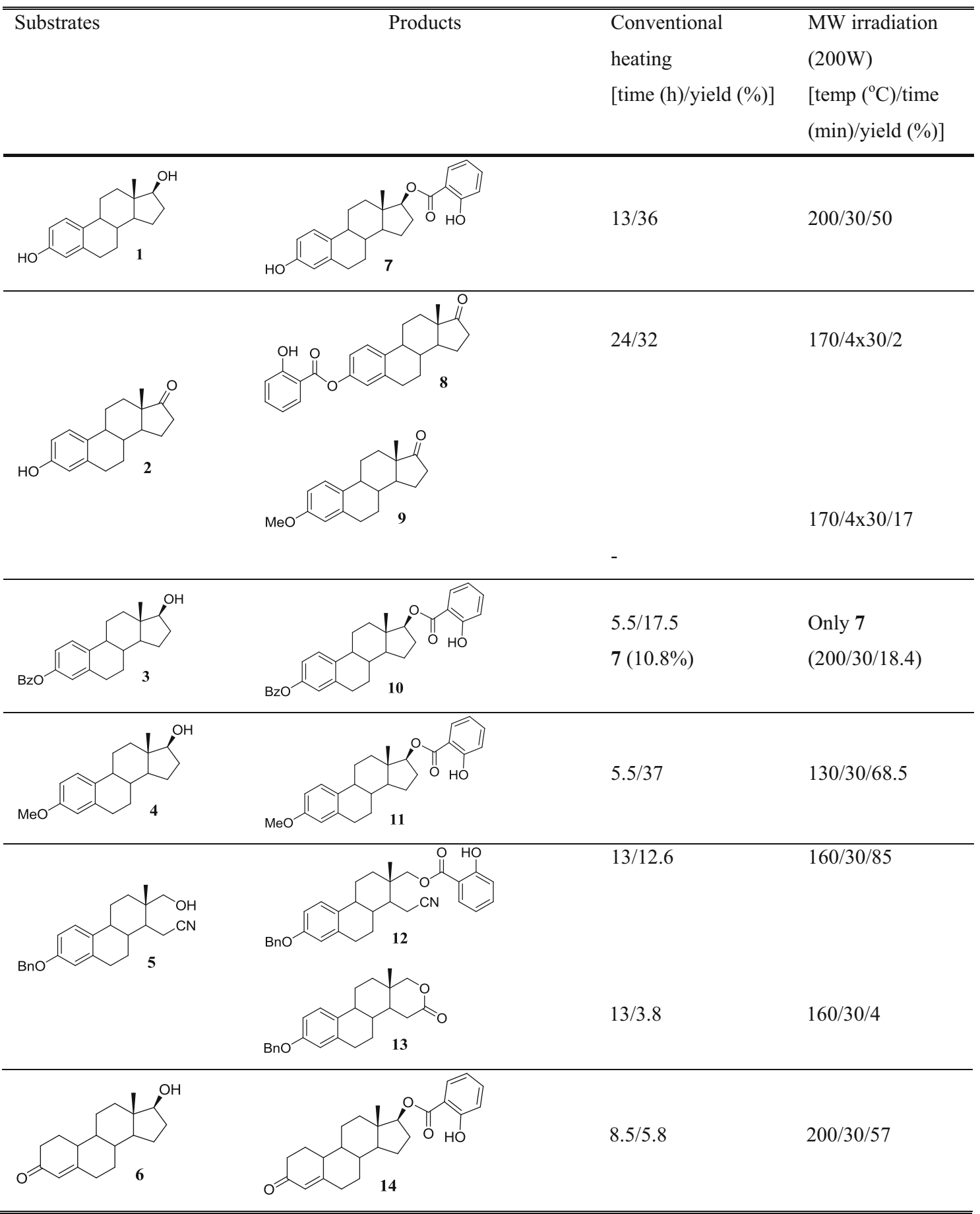

reaction mixture of compound $\mathbf{5}$ and methyl salicylate for 30 min provided compound $\mathbf{1 2}$ at almost sevenfold higher yield $(85 \%)$ than conventional heating conditions $(12.6 \%)$, while the yield of compound $\mathbf{1 3}$ was practically the same $(4 \%)$. The reaction time was shortened 26 -fold.
Transesterification reaction of methyl salicylate with 19-nortestosterone (6) by conventional heating gave 3-oxoestra-4-en-17 $\beta$-yl salicylate (14) at only $5.8 \%$ yield, while MW irradiation resulted in the synthesis of $\mathbf{1 4}$ at $57 \%$ yield. Product yield increased almost tenfold during 
Table 4 Scavenger activity of the selected steroidal compounds

\begin{tabular}{lcc}
\hline Compound & $\mathrm{DPPH}\left(\mathrm{IC}_{50} \mathrm{mM}\right)$ & $\mathrm{OH}\left(\mathrm{IC}_{50} \mathrm{mM}\right)$ \\
\hline $\mathbf{5}$ & $2.85 \pm 0.12$ & $5.70 \pm 0.20$ \\
$\mathbf{7}[29]$ & $0.55 \pm 0.06$ & $0.20 \pm 0.04$ \\
$\mathbf{1 1}$ & $0.16 \pm 0.03$ & $0.95 \pm 0.07$ \\
$\mathbf{1 4}$ & $1.30 \pm 0.07$ & $0.35 \pm 0.04$ \\
Estradiol & $0.497 \pm 0.01$ & $0.004 \pm 0.001$ \\
Methyl salicylate & $0.570 \pm 0.02$ & $0.011 \pm 0.007$ \\
BHT & $0.04 \pm 0.01$ & $1.94 \pm 0.06$ \\
BHA & $0.012 \pm 0.002$ & $2.13 \pm 0.05$
\end{tabular}

Mean antioxidant activity results with standard deviations are presented (mean $\pm \mathrm{SD}$ )

the microwave-assisted reaction, while reaction times decreased 17 -fold.

The structures of the newly synthesized salicyloyl esters $8,10,11,12$ and 14 were deduced on the basis of their IR, NMR and TOF spectra. In IR spectra of 8, 10, 11, 12 and 14, broad shallow bands associated with phenolic $\mathrm{OH}$ stretching vibrations appear at 3205, 3148, 3139, 3187 and $3117 \mathrm{~cm}^{-1}$, respectively, along with strong bands of $\mathrm{C}=\mathrm{O}$ stretching vibrations at $1686 \mathrm{~cm}^{-1}(\mathbf{8}), 1669 \mathrm{~cm}^{-1}(\mathbf{1 0})$, $1669 \mathrm{~cm}^{-1}$ (11), $1676 \mathrm{~cm}^{-1}$ (12) and $1663 \mathrm{~cm}^{-1}$ (14), indicating an intramolecular hydrogen bond between the phenolic $\mathrm{OH}$ group and $\mathrm{C}=\mathrm{O}$ group $(\mathrm{O}-\mathrm{H} \cdot \cdot \mathrm{O}=\mathrm{C})$ within the salicyloyloxy moiety in each molecule. This intramolecular hydrogen bond is also indicated by sharp singlets at $10.55 \mathrm{ppm} \quad(\mathbf{8}), \quad 10.96 \mathrm{ppm} \quad$ (10), $10.91 \mathrm{ppm} \quad$ (11), $10.71 \mathrm{ppm}(\mathbf{1 2})$ and $10.87 \mathrm{ppm}(\mathbf{1 4})$ in the appropriate ${ }^{1} \mathrm{H}$ NMR spectrum $(\mathrm{OH}$ phenolic group from salicyloyl residue). The chemical shifts of $\mathrm{H}-17$ in 10, 11 and 14 (triplets at $4.98,4.95,4.85 \mathrm{ppm}$ ) and those of $\mathrm{H}-17 \mathrm{a}$ and $\mathrm{H}-17 \mathrm{~b}$ in 12 (two doublets at 4.06 and $4.33 \mathrm{ppm}$ ) prove the presence of a salicyloyl group at $\mathrm{C}-17$. The presence of $\mathrm{C}=\mathrm{O}$ from the salicyloyloxy group in $\mathbf{8}, \mathbf{1 0}, \mathbf{1 1}, \mathbf{1 2}$ and $\mathbf{1 4}$ is confirmed by the signals at $169.09,170.08,170.15,169.86$ and $169.97 \mathrm{ppm}$, respectively, in the corresponding ${ }^{13} \mathrm{C}$ NMR spectra.

The antioxidant activity of selected salicylic acid steroidal derivatives was evaluated in in vitro tests and compared with those of parent molecules (estradiol, compound 5 and methyl salicylate), as well as commercial antioxidants BHT and BHA. In the DPPH assay, the ability of the tested compounds to act as hydrogen or electron donors in transforming DPPH to its reduced, stabile form, DPPH-H, was measured spectrophotometrically [29]. The hydroxyl radical scavenging activity of the examined compounds was measured using a deoxyribose assay [29]. The protective effects of the tested compounds on 2-deoxy-D-ribose were assessed as their ability to remove hydroxyl radicals (formed in the Fenton reaction) from the test solution and prevent deoxyribose degradation. The $\mathrm{OH}$ radical scavenging activity of the tested compounds was determined indirectly, by measuring the absorbance of the resulting pink colored solutions.

All tested compounds neutralized DPPH radical (Table 4), while the strongest scavenger activity was displayed by the $17 \beta$-salicyloyloxy derivative $\mathbf{1 1}$, which was more effective than estradiol and methyl salicylate. 17 $\beta$ Salicyloyloxy derivative 14, which has no typical (aromatic) estrane structure of A ring or phenolic group, showed lower DPPH radical scavenging activity than compounds $\mathbf{7}$ and $\mathbf{1 1}$ with 1,3,5(10)-estratriene structures. All tested salicyloyl esters were more effective in $\mathrm{OH}$ radical neutralization than commercially used antioxidants BHT and BHA. 3-Methoxy17-salicyloyloxyestrane derivative 11 expressed fivefold lower activity in $\mathrm{OH}$ radical neutralization than its 3-hydroxy counterpart 7 . D-Seco estrane compound 5, which lacks a phenolic
Table 5 In vitro cytotoxicity of the tested compounds

\begin{tabular}{lllll}
\hline Compound & \multicolumn{1}{l}{$\mathrm{IC}_{50}(\mu \mathrm{M})$} & MDA-MB-231 & PC-3 & MRC-5 \\
\cline { 2 - 5 } & MCF-7 & $>100$ & $>100$ & $>100$ \\
\hline $\mathbf{5}$ & $>100$ & $>100$ & $>100$ & $>100$ \\
$\mathbf{7}[29]$ & $>100$ & $>100$ & $15.54 \pm 1.03$ & $>100$ \\
$\mathbf{8}$ & $57.42 \pm 2.53$ & $>100$ & $26.51 \pm 1.98$ & $>100$ \\
$\mathbf{1 0}$ & $>100$ & $48.78 \pm 3.76$ & $37.68 \pm 2.22$ & $>100$ \\
$\mathbf{1 1}$ & $51.26 \pm 3.68$ & $91.03 \pm 4.69$ & $16.99 \pm 0.98$ & $>100$ \\
$\mathbf{1 2}$ & $>100$ & $>100$ & $>100$ & $>100$ \\
$\mathbf{1 3}$ & $>100$ & $8.99 \pm 1.05$ & $>100$ & $>100$ \\
$\mathbf{1 4}$ & $>100$ & $0.12 \pm 0.02$ & $95.61 \pm 4.36$ & $0.12 \pm 0.01$ \\
$\mathbf{D O X}$ & $0.75 \pm 0.03$ & & & \\
\hline
\end{tabular}

Mean cytotoxicity results with standard deviations are presented (mean \pm SD). Compounds with $\mathrm{IC}_{50}>100 \mu \mathrm{M}$ were considered as non-toxic 
hydroxyl function, was less active than salicyloyl derivatives. Thus, specifically, the structures of rings A, B and D in the tested salicyloyloxy derivatives affect their DPPH and $\mathrm{OH}$ radical neutralization potential.

The estrane compounds $\mathbf{5 , 7 , 8}$ and 10-14 were evaluated for their in vitro cytotoxicity against human breast adenocarcinoma (MCF-7, ER+ and MDA-MB-231, ER-) and prostate cancer cells (PC-3), as well as normal fetal lung fibroblasts (MRC-5). Cytotoxicity was determined using the standard SRB assay, after exposure of cells to test compounds for $48 \mathrm{~h}$ [33]. Doxorubicin served as reference compound and was used as positive control for general toxicity. The results of cytotoxicity assay for the tested compounds are presented in Table 5.

Prostate cancer PC-3 cells were the most sensitive to the tested salicyloyloxy estrane compounds (Table 5). Based on a comparison of $\mathrm{IC}_{50}$ values of $17 \beta$-salicyloyloxy derivatives of estradiol with free (7), 3-benzoyloxy- (10) or 3-methoxy functions (11), higher cytotoxicity against PC-3 cells was observed for compounds $\mathbf{1 0}$ and $\mathbf{1 1}$, indicating the favorable influence of substituents at the $\mathrm{C} 3$ position. Steroidal esters of salicylic acid $\mathbf{8 , 1 0}$ and $\mathbf{1 2}$ showed good cytotoxicity against PC-3 cells, while compound $\mathbf{1 1}$ expressed moderate activity against all malignant cells. Significantly increased antiproliferative activity against PC-3 cells was observed for the D-seco salicyloyloxy derivative $\mathbf{1 2}$, compared to its precursor $\mathbf{5}$, probably due to the presence of the salicyloyl function in $\mathbf{1 2}$.

Most of the tested compounds exhibited higher activity against PC-3 cells than doxorubicin (DOX). Note that DOX controls showed low cytotoxicity against PC-3-cells $\left(\mathrm{IC}_{50} 95.61 \mu \mathrm{M}\right)$, in agreement with reported values [44]. The most active compounds against this cell line were salicyloyloxy derivatives $\mathbf{8}$ and $\mathbf{1 2}$, which were approximately four times more active than doxorubicin. Doxorubicin was extremely toxic to normal noncancerous MRC-5 cells, consistent with its nonspecific cellular cytotoxicity. In contrast, none of the tested steroidal compounds were toxic to healthy non-cancerous cells (MRC$5)$.

Against ER-human breast adenocarcinoma cells (MDA-MB-231), only 17 $\beta$-salicyloyloxy 19-nor-testosterone $\mathbf{1 4}\left(\mathrm{IC}_{50} 8.99 \mu \mathrm{M}\right)$, with a 4-ene-3-one moiety in $\mathrm{A}$ ring, exhibited fairly strong activity. However, salicyloyloxy derivatives with a planar estra-1,3,5(10)-triene moiety in the A ring (7, 8, 10 and 12) are inactive against MDAMB-231 cells with the exception of compound $\mathbf{1 1}$ which showed weak activity.

Estrane derivatives without a salicyloyl group, $\mathbf{5}$ and $\mathbf{1 3}$, did not exhibit cytotoxic activity against neoplastic cells indicating that the salicyloyl functional group has a positive influence on the cytotoxicity of these compounds.

Hydroxysteroid dehydrogenase enzymes (HSDs) are involved in the biosynthetic pathways of steroid hormones, so their inhibition represents an interesting approach for the treatment of steroid-dependent diseases. The inhibitory effects of specific steroidal compounds on selected HSDs were tested, in order to assess their potential to prevent the peripheral interconversion of steroid hormones between their active and inactive forms.

The inhibitory effects of selected compounds on human placental $17 \beta \mathrm{HSD} 1$ and rat testicular $17 \beta \mathrm{HSD} 3$ activity were investigated by in vitro radio-substrate incubation methods. Inhibition activities of salicyloyloxy estrane derivatives 7, 10-12 and 14 against human 17ßHSD1 and rat $17 \beta$ HSD3 were very weak (Table 6). 17 $\beta$-Salicyloyl ester of estradiol 7 efficiently inhibited rat testicular $3 \beta \mathrm{HSD}\left(\mathrm{IC}_{50} 9.3 \mu \mathrm{M}\right)$, while other tested salicyloyloxy

Table 6 In vitro inhibition of $3 \beta \mathrm{HSD}, 17 \beta \mathrm{HSD} 1,17 \beta \mathrm{HSD} 2$ and $17 \beta \mathrm{HSD} 3$ by selected steroidal compounds; non-inhibited controls are set as $100 \%$

\begin{tabular}{|c|c|c|c|c|}
\hline Compound & $\begin{array}{l}\text { r3 } \beta \text { HSD } \\
\text { Relative conversion } \pm \mathrm{SD} \\
(\% \text { at } 50 \mu \mathrm{M})\end{array}$ & $\begin{array}{l}\text { h17 } \beta \text { HSD } 1 \\
\text { Relative conversion } \pm \mathrm{SD} \\
(\% \text { at } 50 \mu \mathrm{M})\end{array}$ & $\begin{array}{l}\text { r17 } \beta \mathrm{HSD} 2 \\
\text { Relative conversion } \pm \mathrm{SD} \\
(\% \text { at } 50 \mu \mathrm{M})\end{array}$ & $\begin{array}{l}\text { r17 } \beta \text { HSD3 } \\
\text { Relative conversion } \pm \mathrm{SD} \\
(\% \text { at } 50 \mu \mathrm{M})\end{array}$ \\
\hline 7 & $\begin{array}{l}14 \pm 1.5 \\
\mathrm{IC}_{50}=9.3 \pm 1.3 \mu \mathrm{M}\end{array}$ & $52 \pm 5$ & $\begin{array}{l}4.3 \pm 1.4 \\
\mathrm{IC}_{50}=0.59 \pm 0.10 \mu \mathrm{M}\end{array}$ & $95 \pm 6$ \\
\hline 10 & NI & $92 \pm 11$ & $87 \pm 14$ & $\mathrm{NI}$ \\
\hline 11 & $91 \pm 1$ & $81 \pm 17$ & $90 \pm 6$ & $95 \pm 4$ \\
\hline 12 & $85 \pm 2$ & $56 \pm 13$ & $\begin{array}{l}53 \pm 5 \\
\mathrm{IC}_{50}=51 \pm 2 \mu \mathrm{M}\end{array}$ & $83 \pm 5$ \\
\hline 14 & $87 \pm 5$ & $76 \pm 5$ & $\begin{array}{l}34 \pm 3 \\
\mathrm{IC}_{50}=13 \pm 1.5 \mu \mathrm{M}\end{array}$ & $\mathrm{NI}$ \\
\hline
\end{tabular}

Mean enzyme activity results, expressed as relative conversion of substrate, with standard deviations are presented (mean \pm SD)

NI no inhibition 


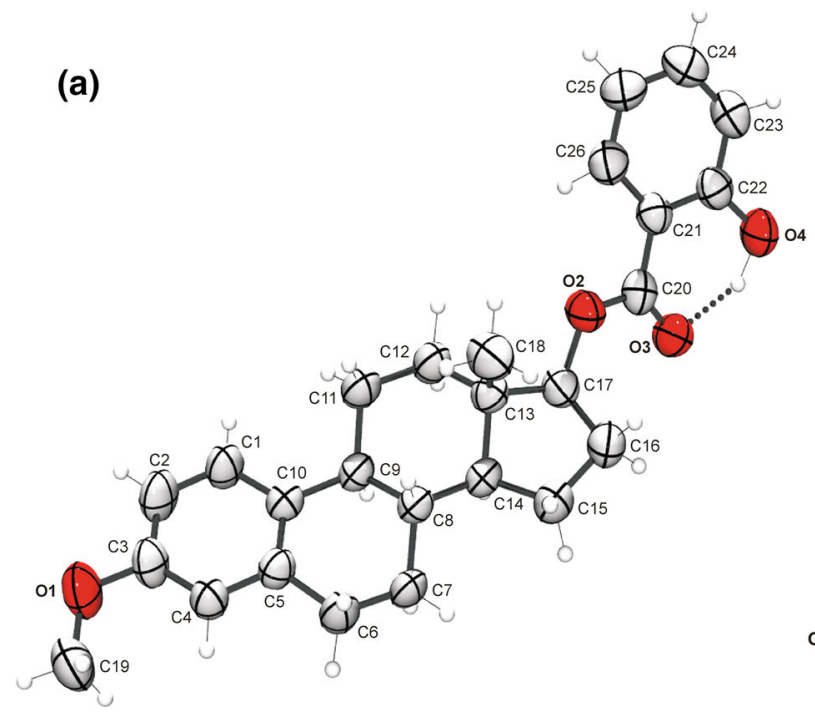

Fig. 1 ORTEP [45] drawings of the molecular structures of compounds 11 (a), 14 (b) with labeling of non-H atoms. Displacement ellipsoids are shown at the $50 \%$ probability level, and $\mathrm{H}$ atoms are

derivatives only weakly inhibited this enzyme. Three of the five tested substances expressed significant inhibitory effects on $17 \beta \mathrm{HSD} 2$ activity. 17 $\beta$-Salicyloyl ester of nortestosterone 14 significantly inhibited this $17 \beta \mathrm{HSD}$ isoform, D-secoestrane salicyloyloxy derivative 12 displayed moderate inhibitory activity, whereas the $17 \beta$-salicyloyl ester of estradiol 7 strongly inhibited this isozyme $\left(\mathrm{IC}_{50} 0.59 \mu \mathrm{M}\right)$. These results suggest the potential of $\mathbf{7}$ as a lead compound for modeling and synthesis of therapeutics for the treatment of pathological conditions caused by estrogen depletion, e.g., osteopenia or osteoporosis.

ORTEP [45] drawings of the molecular structures of $\mathbf{1 1}$ and $\mathbf{1 4}$ are depicted in Fig. 1, while selected bond distances, bond angles and torsion angles within these compounds are given in Table 7. Compound $\mathbf{1 1}$ crystallizes in the monoclinic non-centrosymmetric $P 2_{1}$ space group with two molecules in the unit cell, while compound $\mathbf{1 4}$ crystallizes in the orthorhombic $P 2_{1} 2_{1} 2_{1}$ space group with four molecules in the unit cell. Intramolecular geometry analysis showed that bond lengths, angles and torsion angles in molecule of compound $\mathbf{1 1}$ are in agreement with those in the same region (excluding the $\mathrm{C} 3$ functional groups) of compound 14 (Table 7).

The ABCD steroid backbone of $\mathbf{1 1}$ has a methyl group attached to $\mathrm{C} 13$ and shows trans $\mathrm{C} / \mathrm{D}$ ring junctions. The molecular region consisting of the methoxy group and aromatic A ring in $\mathbf{1 1}$ is almost perfectly planar with the torsion angle $\mathrm{C} 2-\mathrm{C} 3-\mathrm{O} 1-\mathrm{C} 19$ equal to $175.0(3)^{\circ}$ and $\mathrm{C} 4-$ C3-O1-C19 equal to $-3.4(4)^{\circ}$. The $\mathrm{B}$ ring in $\mathbf{1 1}$ has a $7 \alpha, 8 \beta$-halfchair $\left.{ }_{3} \mathrm{H}^{4}\right)$ conformation (puckering parameters [46] presented in Table 8 where the calculation starts from C5 to C10 and proceeds in a counter-clockwise direction). (b)

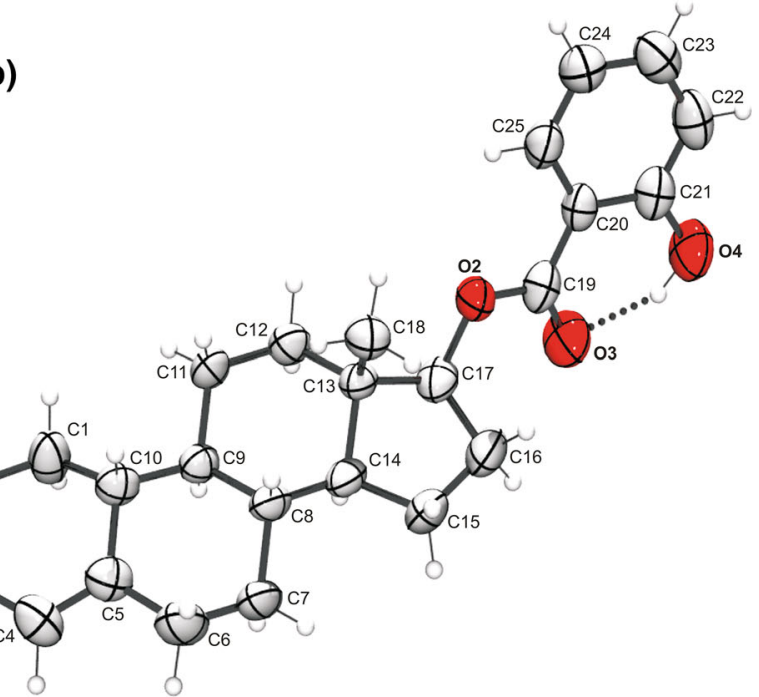

drawn as spheres of arbitrary radii. Intramolecular hydrogen bonds are shown as dashed lines

The best rotational axis bisects $\mathrm{C} 7-\mathrm{C} 8$ and $\mathrm{C} 5-\mathrm{C} 10$ bonds with asymmetry parameters [47] $\Delta \mathrm{C}_{2}=3.3(4)^{\circ}$. The weighted average absolute torsion angle is $39.68(14)^{\circ}$, and weighted average ring bond distance is $1.4988(16) \AA$. Ring $\mathrm{C}$ in $\mathbf{1 1}$ has an almost perfect $8 \beta, 12 \alpha$-chair $\left({ }^{1} \mathrm{C}_{4}\right)$ conformation where the calculation starts from $\mathrm{C} 8$ to $\mathrm{C} 14$ and proceeds in a clockwise direction (Table 8) with selected asymmetry parameters: $\Delta \mathrm{C}_{\mathrm{s}}(\mathrm{C} 11)=0.7(2)^{\circ}, \quad \Delta \mathrm{C}_{2}(\mathrm{C} 9$ $\mathrm{C} 11)=2.4(3)^{\circ}, \quad \Delta \mathrm{C}_{2}(\mathrm{C} 11-\mathrm{C} 12)=3.5(3)^{\circ}, \quad \Delta \mathrm{C}_{2}(\mathrm{C} 12-$ $\mathrm{C} 13)=5.0(3)^{\circ}$ and a weighted average absolute torsion angle of $55.70(13)^{\circ}$ and weighted average ring bond distance of 1.5263(16) $\AA$. Ring D in $\mathbf{1 1}$ has a $13 \beta$-envelope $\left({ }^{1}\right.$ E) conformation deformed toward a $13 \beta, 14 \alpha$-halfchair $\left({ }^{1} \mathrm{~T}_{2}\right)$ conformation, where the calculation starts from $\mathrm{C} 13$ to $\mathrm{C} 17$ and proceeds in a counter-clockwise direction (Table 8 ) with the best mirror plane passing through $\mathrm{C} 13$ with $\Delta \mathrm{C}_{\mathrm{s}}=7.8(3)^{\circ}$ and rotational symmetry with $\Delta \mathrm{C}_{2}(\mathrm{C} 13-\mathrm{C} 14)=13.2(3)^{\circ}$. The weighted average absolute torsion angle for ring $\mathrm{D}$ in $\mathbf{1 1}$ is $30.28(13)^{\circ}$, and the weighted average ring bond distance is $1.5274(18) \AA$.

The keto group bonded to $\mathrm{C} 3$ disturbs the $\mathrm{A}$ ring conformation in $\mathbf{1 4}$. The $\mathrm{A}$ ring in $\mathbf{1 4}$ has a $1 \alpha$-envelope $\left(\mathrm{E}_{1}\right)$ conformation slightly deformed toward a $1 \alpha, 2 \beta$-halfchair $\left({ }^{2} \mathrm{H}_{1}\right)$ (puckering parameters presented in Table 8 where the calculation starts from $\mathrm{C} 1$ to $\mathrm{C} 10$ and proceeds in a counterclockwise direction). Distortion from the ideal form could be expressed through asymmetry parameters due to the loss of mirror symmetry through $\mathrm{C} 1$ atom $\left[\Delta \mathrm{C}_{\mathrm{s}}(\mathrm{C} 1)=7.8(3)^{\circ}\right]$ and rotational symmetry $\left[\Delta \mathrm{C}_{2}(\mathrm{C} 1-\mathrm{C} 2)=19.3(3)^{\circ}\right]$. The weighted average absolute torsion angle is $29.79(13)^{\circ}$, and weighted average ring bond distance is $1.4904(14) \AA$. The B ring in $\mathbf{1 4}$ has a $5 \alpha, 8 \beta$-chair $\left({ }_{1} \mathrm{C}^{4}\right)$ conformation (puckering 
Table 7 Selected bond lengths $(\AA)$ and angles $\left({ }^{\circ}\right)$

\begin{tabular}{|c|c|c|c|}
\hline \multicolumn{2}{|l|}{ Compound 11} & \multicolumn{2}{|l|}{ Compound 14} \\
\hline Bond & & Bond & \\
\hline $\mathrm{O} 2-\mathrm{C} 20$ & $1.324(3)$ & $\mathrm{O} 2-\mathrm{C} 19$ & $1.333(2)$ \\
\hline $\mathrm{O} 2-\mathrm{C} 17$ & $1.465(3)$ & $\mathrm{O} 2-\mathrm{C} 17$ & $1.453(3)$ \\
\hline $\mathrm{O} 3-\mathrm{C} 20$ & $1.217(3)$ & $\mathrm{O} 3-\mathrm{C} 19$ & $1.225(2)$ \\
\hline $\mathrm{O} 4-\mathrm{C} 22$ & $1.350(4)$ & $\mathrm{O} 4-\mathrm{C} 21$ & $1.356(3)$ \\
\hline $\mathrm{O} 1-\mathrm{C} 3$ & $1.384(3)$ & $\mathrm{O} 1-\mathrm{C} 3$ & $1.222(3)$ \\
\hline Angle & & Angle & \\
\hline $\mathrm{C} 20-\mathrm{O} 2-\mathrm{C} 17$ & $118.8(2)$ & $\mathrm{C} 19-\mathrm{O} 2-\mathrm{C} 17$ & $117.97(17)$ \\
\hline $\mathrm{O} 3-\mathrm{C} 20-\mathrm{O} 2$ & $123.0(3)$ & $\mathrm{O} 3-\mathrm{C} 19-\mathrm{O} 2$ & $122.0(2)$ \\
\hline $\mathrm{O} 3-\mathrm{C} 20-\mathrm{C} 21$ & $124.2(3)$ & O3-C19-C20 & $124.6(2)$ \\
\hline $\mathrm{O} 2-\mathrm{C} 20-\mathrm{C} 21$ & $112.7(3)$ & $\mathrm{O} 2-\mathrm{C} 19-\mathrm{C} 20$ & $113.40(19)$ \\
\hline $\mathrm{O} 4-\mathrm{C} 22-\mathrm{C} 23$ & $117.6(3)$ & $\mathrm{O} 4-\mathrm{C} 21-\mathrm{C} 22$ & $118.1(2)$ \\
\hline $\mathrm{O} 4-\mathrm{C} 22-\mathrm{C} 21$ & $122.6(3)$ & $\mathrm{O} 4-\mathrm{C} 21-\mathrm{C} 20$ & $122.0(2)$ \\
\hline $\mathrm{O} 2-\mathrm{C} 17-\mathrm{C} 16$ & $113.9(2)$ & $\mathrm{O} 2-\mathrm{C} 17-\mathrm{C} 16$ & $112.57(18)$ \\
\hline $\mathrm{O} 2-\mathrm{C} 17-\mathrm{C} 13$ & $109.3(2)$ & $\mathrm{O} 2-\mathrm{C} 17-\mathrm{C} 13$ & $110.18(15)$ \\
\hline Torsion angle & & Torsion angle & \\
\hline $\mathrm{O} 1-\mathrm{C} 3-\mathrm{C} 2-\mathrm{C} 1$ & $-177.2(2)$ & $\mathrm{C} 1-\mathrm{C} 2-\mathrm{C} 3-\mathrm{O} 1$ & $-155.8(2)$ \\
\hline $\mathrm{C} 5-\mathrm{C} 4-\mathrm{C} 3-\mathrm{O} 1$ & $176.7(2)$ & $\mathrm{O} 1-\mathrm{C} 3-\mathrm{C} 4-\mathrm{C} 5$ & $-173.9(2)$ \\
\hline $\mathrm{C} 17-\mathrm{O} 2-\mathrm{C} 20-\mathrm{O} 3$ & $-7.3(4)$ & $\mathrm{C} 17-\mathrm{O} 2-\mathrm{C} 19-\mathrm{O} 3$ & $4.8(3)$ \\
\hline $\mathrm{C} 17-\mathrm{O} 2-\mathrm{C} 20-\mathrm{C} 21$ & $174.5(2)$ & $\mathrm{C} 17-\mathrm{O} 2-\mathrm{C} 19-\mathrm{C} 20$ & $-173.48(17)$ \\
\hline $\mathrm{O} 3-\mathrm{C} 20-\mathrm{C} 21-\mathrm{C} 22$ & $-8.5(4)$ & $\mathrm{C} 21-\mathrm{C} 20-\mathrm{C} 19-\mathrm{O} 3$ & $-8.6(3)$ \\
\hline $\mathrm{O} 3-\mathrm{C} 20-\mathrm{C} 21-\mathrm{C} 26$ & $170.1(3)$ & $\mathrm{C} 25-\mathrm{C} 20-\mathrm{C} 19-\mathrm{O} 3$ & $172.67(19)$ \\
\hline $\mathrm{C} 20-\mathrm{C} 21-\mathrm{C} 22-\mathrm{O} 4$ & $0.7(4)$ & $\mathrm{C} 19-\mathrm{C} 20-\mathrm{C} 21-\mathrm{O} 4$ & $1.4(3)$ \\
\hline $\mathrm{C} 26-\mathrm{C} 21-\mathrm{C} 22-\mathrm{O} 4$ & $-178.0(3)$ & $\mathrm{C} 25-\mathrm{C} 20-\mathrm{C} 21-\mathrm{O} 4$ & $-179.76(19)$ \\
\hline $\mathrm{C} 20-\mathrm{O} 2-\mathrm{C} 17-\mathrm{C} 13$ & $-168.4(2)$ & $\mathrm{C} 19-\mathrm{O} 2-\mathrm{C} 17-\mathrm{C} 13$ & $-176.58(16)$ \\
\hline $\mathrm{C} 20-\mathrm{O} 2-\mathrm{C} 17-\mathrm{C} 16$ & $73.4(3)$ & C19-O2-C17-C16 & $65.5(2)$ \\
\hline $\mathrm{C} 12-\mathrm{C} 13-\mathrm{C} 17-\mathrm{O} 2$ & $77.2(3)$ & $\mathrm{C} 12-\mathrm{C} 13-\mathrm{C} 17-\mathrm{O} 2$ & $83.6(2)$ \\
\hline $\mathrm{C} 14-\mathrm{C} 13-\mathrm{C} 17-\mathrm{O} 2$ & $-165.8(2)$ & $\mathrm{C} 14-\mathrm{C} 13-\mathrm{C} 17-\mathrm{O} 2$ & $-161.09(16)$ \\
\hline $\mathrm{C} 18-\mathrm{C} 13-\mathrm{C} 17-\mathrm{O} 2$ & $-48.4(3)$ & $\mathrm{C} 18-\mathrm{C} 13-\mathrm{C} 17-\mathrm{O} 2$ & $-43.2(2)$ \\
\hline $\mathrm{O} 2-\mathrm{C} 17-\mathrm{C} 16-\mathrm{C} 15$ & $142.8(3)$ & $\mathrm{O} 2-\mathrm{C} 17-\mathrm{C} 16-\mathrm{C} 15$ & $138.72(19)$ \\
\hline
\end{tabular}

parameters presented in Table 8 where the calculation starts from $\mathrm{C} 5$ to $\mathrm{C} 10$ and proceeds in a counter-clockwise direction). Rotational symmetry is presented with the best rotational axis bisecting $\mathrm{C} 7-\mathrm{C} 8$ and $\mathrm{C} 10-\mathrm{C} 5$ bonds with $\Delta \mathrm{C}_{2}=3.6(3)^{\circ}$. The best mirror plane passes through $\mathrm{C} 5$ and $\mathrm{C} 8$ with $\Delta \mathrm{C}_{\mathrm{s}}=4.6(2)^{\circ}$. The weighted average absolute torsion angle is $49.75(12)^{\circ}$, and weighted average ring bond distance is $1.5244(13) \AA$. Ring $C$ in $\mathbf{1 4}$ has a $8 \beta, 12 \alpha$-chair $\left({ }^{1} \mathrm{C}_{4}\right)$ conformation that is typically distorted in the crystalline state (puckering parameters presented in Table 8 where the calculation starts from $\mathrm{C} 8$ to $\mathrm{C} 14$ and proceeds in
Table 9 Hydrogen bond parameters $\left(\AA{ }^{\circ}{ }^{\circ}\right)$

\begin{tabular}{|c|c|c|c|c|}
\hline $\mathrm{D}-\mathrm{H} \cdots \mathrm{A}$ & $\mathrm{D}-\mathrm{H}$ & $\mathrm{H} \cdots \mathrm{A}$ & $\mathrm{D} \cdots \mathrm{A}$ & $\mathrm{D}-\mathrm{H} \cdots \mathrm{A}$ \\
\hline \multicolumn{5}{|l|}{ Compound 11} \\
\hline $\mathrm{O} 4-\mathrm{H} 4 \cdots \mathrm{O} 3$ & $1.02(5)$ & $1.70(5)$ & $2.605(3)$ & $146(4)$ \\
\hline $\begin{array}{l}\text { C19-H19B } \cdots \mathrm{O} 4 \\
\quad[1+\mathrm{x}, \mathrm{y}, 1+\mathrm{z}]\end{array}$ & 0.96 & 2.43 & $3.374(4)$ & 166 \\
\hline \multicolumn{5}{|l|}{ Compound 14} \\
\hline $\mathrm{O} 4-\mathrm{H} 4 \cdots \mathrm{O} 3$ & $0.91(3)$ & $1.78(3)$ & $2.609(3)$ & $150(3)$ \\
\hline
\end{tabular}

a clockwise direction). The best rotational axis bisects $\mathrm{C} 9$ $\mathrm{C} 11$ and $\mathrm{C} 13-\mathrm{C} 14$ bonds with $\Delta \mathrm{C}_{2}=3.1(2)^{\circ}$. The best mirror plane passes through $\mathrm{C} 11$ and $\mathrm{C} 14$ with $\Delta \mathrm{C}_{\mathrm{s}}=$ 2.31(16) ${ }^{\circ}$. The weighted average absolute torsion angle in $\mathrm{C}$ ring is $54.92(8)^{\circ}$, and weighted average ring bond distance is 1.5273(12) ̊. Five-membered ring D in $\mathbf{1 4}$ has a $13 \beta, 14 \alpha$ halfchair $\left({ }^{1} \mathrm{~T}_{2}\right)$ distorted to a $13 \beta$-envelope $\left({ }^{1} \mathrm{E}\right)$ conformation (puckering parameters presented in Table 8 where the calculation starts from $\mathrm{C} 13$ to $\mathrm{C} 17$ and proceeds in a counter-clockwise direction) with asymmetry parameters $\Delta \mathrm{C}_{\mathrm{s}}(\mathrm{C} 13)=13.2(2)^{\circ}$ and $\Delta \mathrm{C}_{2}(\mathrm{C} 13-\mathrm{C} 14)=6.0(3)^{\circ}$ with a weighted average absolute torsion angle of $34.40(10)^{\circ}$ and weighted average ring bond distance of 1.5354(14) A.

Information on intramolecular hydrogen bonding is very important for understanding various molecular properties, including molecular geometry and the stability of predominant conformations and, consequently, the biological activity of a compound of interest. As can be seen in Fig. 1, both 11 and 14 contain intramolecular $\mathrm{O} 4-\mathrm{H} 4 \cdots \mathrm{O} 3$ hydrogen bonds. Hydrogen bond parameters are given in Table 9.

The crystal packings of $\mathbf{1 1}$ and $\mathbf{1 4}$ are illustrated in Fig. 2. The crystal packing of $\mathbf{1 1}$ is arranged by C19H19B $\cdots$ O 4 (Table 9) contacts where these intermolecular interactions lead to infinite planes of head to tail connected molecules. Atom $\mathrm{O} 4$ in $\mathbf{1 1}$ acts as acceptor in both intramolecular $\mathrm{O} 4-\mathrm{H} 4 \cdots \mathrm{O} 3$ hydrogen bond and intermolecular C19-H19B ‥O4 contact (Fig. 3). The crystal packing of $\mathbf{1 4}$ is dominantly arranged by van der Waals forces and corresponds to a discrete arrangement of molecules (Fig. 2). We have not found classic hydrogen bonding or other contacts in the intermolecular space of $\mathbf{1 4}$.

Comparing the molecular structures of $\mathbf{1 1}$ and 14, we observed minor differences in conformation among rings $\mathrm{C}$
Table 8 The puckering parameters for compounds $\mathbf{1 1}$ and $\mathbf{1 4}$

\begin{tabular}{|c|c|c|c|c|c|c|c|}
\hline & \multicolumn{3}{|c|}{ Compound 11} & \multicolumn{4}{|c|}{ Compound 14} \\
\hline & $\mathrm{B}$ ring & $\mathrm{C}$ ring & $\mathrm{D}$ ring & A ring & $\mathrm{B}$ ring & $\mathrm{C}$ ring & $\mathrm{D}$ ring \\
\hline$Q(\AA)$ & $0.495(3)$ & $0.568(3)$ & $0.458(3)$ & $0.450(3)$ & $0.521(3)$ & $0.565(2)$ & $0.455(2)$ \\
\hline$\theta\left({ }^{\circ}\right)$ & $45.2(3)$ & $2.5(3)$ & - & $54.6(4)$ & $15.6(3)$ & $6.3(2)$ & - \\
\hline$\varphi\left(^{\circ}\right)$ & $154.7(5)$ & $299(6)$ & 188.1(4) & $8.2(4)$ & $165.5(11)$ & $279(2)$ & 193.4(3) \\
\hline
\end{tabular}



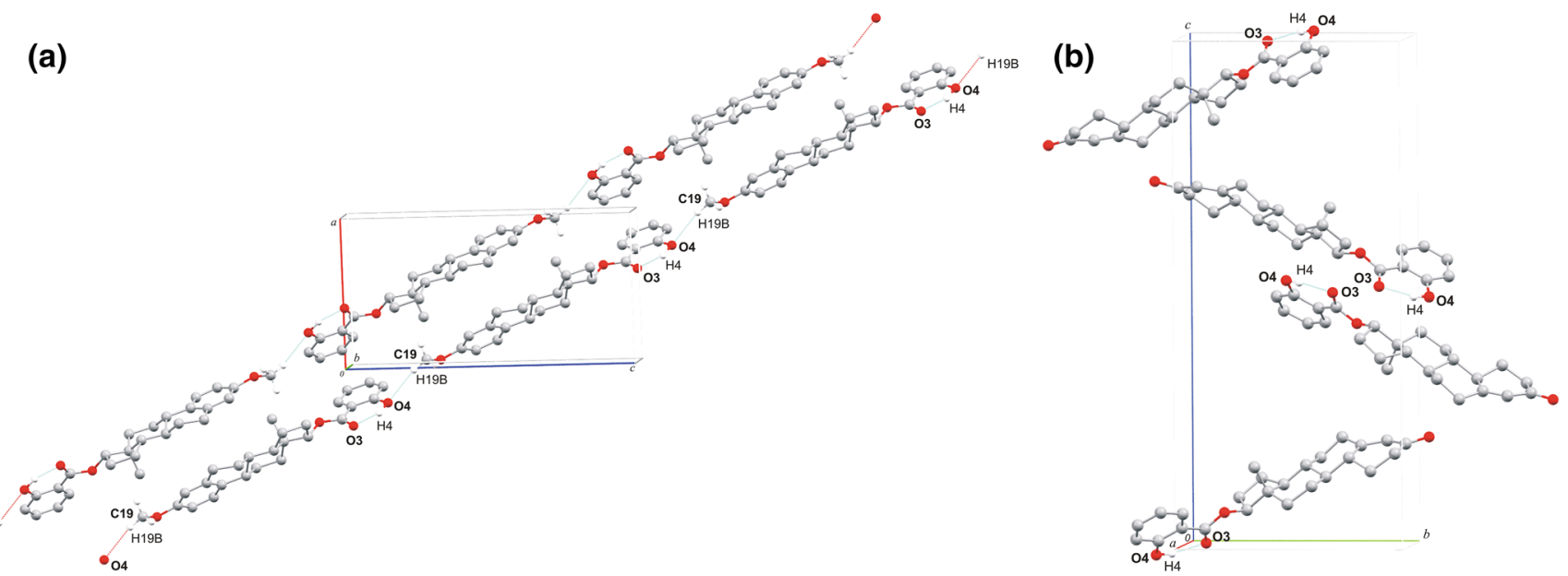

Fig. 2 MERCURY [49] drawings showing the crystal packing of: a compound $\mathbf{1 1}$ (along $b$ axis) and b compound $\mathbf{1 4}$ (along $a$-axis)

(a)

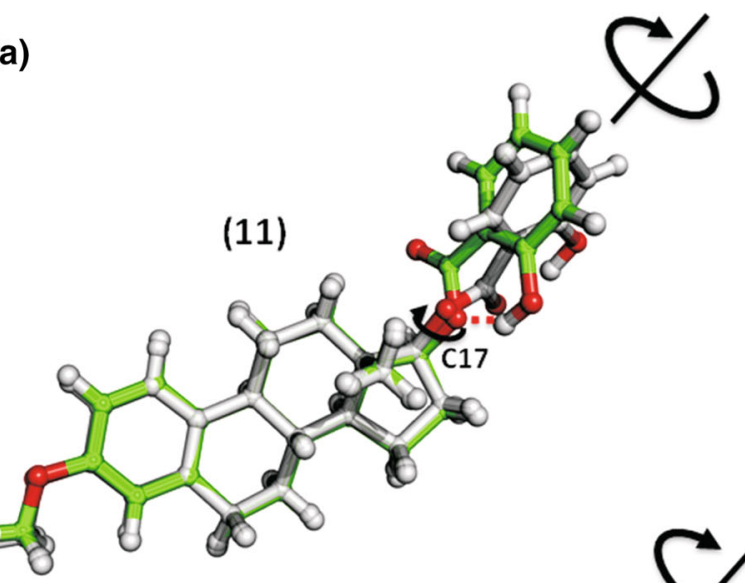

(b)

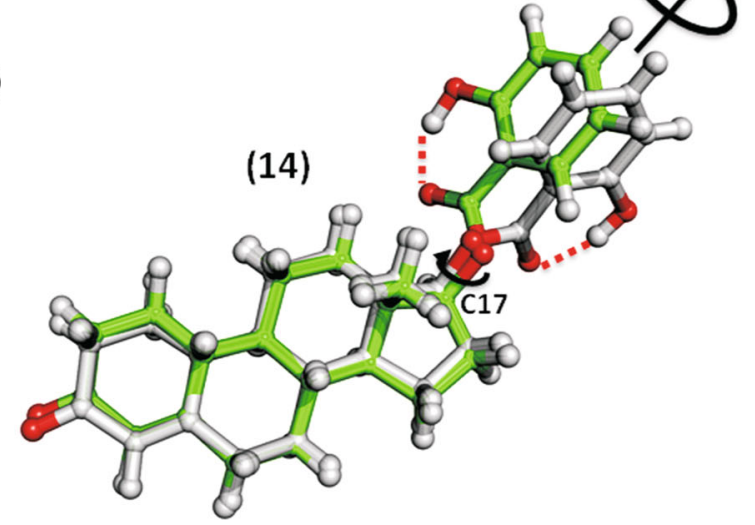

Fig. 3 Superimposed fit of the molecules after conjugate energy minimization ( $\mathrm{C}$ atoms in green) and the molecule in the crystalline state (C atoms in white): a compound $\mathbf{1 1}$ and b compound $\mathbf{1 4}$. Hydrogen bonds observed during energy minimization for $\mathbf{1 1}$ and $\mathbf{1 4}$ are shown as red dashed lines (Color figure online)

and D across $\mathbf{1 1}$ and $\mathbf{1 4}$ which may be attributed to the different intermolecular interactions. On the other hand, when rings $\mathrm{A}$ and $\mathrm{B}$ in $\mathbf{1 1}$ and $\mathbf{1 4}$ are compared, it is clear, as expected, that the modifications introduced in the A rings (methoxy group bonded to $\mathrm{C} 3$ in aromatic $\mathrm{A}$ ring in 11 and keto group bonded to $\mathrm{C} 3$ in 14) produce some conformational changes in the steroid framework.

To complement our investigation of the cytotoxicity of compounds 11 and 14, we determined the conformation of the molecules released from the influence of the crystalline field, i.e., the next step was to define the conformations of 11 and $\mathbf{1 4}$ in terms of energy minima. Both X-ray crystal structures of compounds $\mathbf{1 1}$ and $\mathbf{1 4}$ were subjected to exhaustive conjugate gradient energy minimization using an MMFF94 force field (convergence setting of $10 \mathrm{e}-7 \mathrm{~kJ} / \mathrm{mol}$ ), followed by molecular mechanics conformer analysis using a systematic rotomer search in the program Avogadro [48].

For compound 11 with four rotatable bonds, 899 conformers were tested. For compound $\mathbf{1 4}$ with three rotatable bonds, 149 conformers were tested. For both $\mathbf{1 1}$ and 14, conformer analysis indicates conformational flexibility in the form of rotation around the $\mathrm{C} 17 \cdots \mathrm{O} 2$ bond (indicated by black arrows in Fig. 3) resulting in conformers of nearly equal energy (range $410.25-520.47 \mathrm{~kJ} / \mathrm{mol}$ for $\mathbf{1 1}$ and $357.38-461.34 \mathrm{~kJ} / \mathrm{mol}$ for 14$)$. On the other hand, very good overlap in the region of the steroidal nucleus (excluding the $\mathrm{C} 3$ functional group) was observed for the molecular structures of molecules $\mathbf{1 1}$ and $\mathbf{1 4}$ in the crystalline state and after energy optimization (Fig. 3). The $\mathrm{O} 4-\mathrm{H} 4 \cdots \mathrm{O} 3$ hydrogen bond (indicated by a red dashed line in Fig. 3) observed in the X-ray crystal structures of compounds $\mathbf{1 1}$ and $\mathbf{1 4}$ is maintained following energy minimization and conformer analysis.

In our previous study [28], we reported the crystal structure of (3-oxo-5 $\alpha$-androstan-17 $\beta$-yl)-2-methoxybenzoate (15) (Fig. 4a) as well as its strong cytotoxicity against MDA-MB-231 cells $\left(\mathrm{IC}_{50} 3.45 \mu \mathrm{M}\right)$. Structural superposition of $\mathbf{1 4}$ with previously reported compound $\mathbf{1 5}$ (with comparable antiproliferative activity against MDA- 
Fig. 4 a Structural formulas of the compounds whose structural superpositions are studied. b Structural superposition of $\mathbf{1 4}$ with a previously reported compound 15. c Structural superposition of $\mathbf{1 1}$ with compound 15. Hydrogen bonds observed during energy minimization for $\mathbf{1 1}$ and $\mathbf{1 4}$ are shown as red dashed lines (Color figure online)<smiles>COc1ccc2c(c1)CCC1C2CC[C@]2(C)C(OC(=O)c3ccccc3O)CCC12</smiles><smiles>C[C@]12CCC3CCC(=O)C=C3CCC1C1CCC(OC(=O)c3ccccc3O)[C@@H]12</smiles><smiles>COc1ccccc1C(=O)O[C@H]1CCC2C3CC[C@@H]4CC(=O)CC[C@]4(C)C3CC[C@]21C</smiles>

(c)

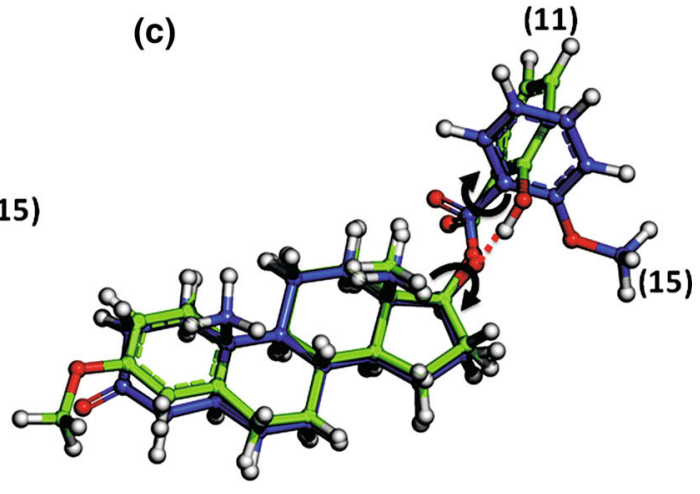

MB-231 breast cancer cells, $\mathrm{IC}_{50} 8.99 \mu \mathrm{M}$ vs. $3.45 \mu \mathrm{M}$ ) showed rotation around the $\mathrm{C} 17 \cdots \mathrm{O} 2$ bond during conformer analysis (indicated by black arrows in Fig. 4b), while a very good overlap in the region of steroidal nucleus was observed.

Structural superposition of 11, which has moderate antiproliferative activity against MDA-MB-231 ( $\mathrm{IC}_{50}$ $48.78 \mu \mathrm{M}$ ), with compound 15 revealed significant structural differences between 11 and $\mathbf{1 5}$ in the A ring (Fig. 4c), and conformational flexibility around the $\mathrm{C} 17 \cdots \mathrm{O} 2$ bond was also observed for $\mathbf{1 1}$ and $\mathbf{1 5}$ during conformer analysis (indicated by black arrows in Fig. 4c). It seems that the structural geometry in the region of ring A and especially the C3 functional group is important structural features influencing antiproliferative activity against MDA-MB-231.

\section{Conclusions}

Based on a comparison of transesterification reactions of methyl salicylate with steroidal alcohols or phenols 1-6 by MW irradiation versus conventional heating, the MW-assisted method considerably accelerated reactions 11 - to 26fold. In the case of starting steroidal compounds $\mathbf{1 , 4 , 5}$ and 6, MW-assisted reactions also resulted in considerably higher total product yields.

New estrane salicyloyloxy derivatives expressed antioxidative and/or antiproliferative potential. It can be concluded based on X-ray analysis that the structural geometry in the region of ring A and especially the structure of the $\mathrm{C} 3$ functional group in the synthesized compounds is important structural features concerning antiproliferative activity against MDA-MB-231 cell lines. On the other hand, new compounds were selective in their inhibition of steroidogenesis enzymes. Because of the selectivity of some tested salicyloyloxy estrane derivatives toward different HSDs, inhibitors of 17 $\beta$-HSD2 described here may prove beneficial for conditions in which the concentration of active steroid is too low.

\section{Supplementary data}

CCDC 1408660-1408661 contains supplementary crystallographic data for this paper. These data are available free of charge at www.ccdc.cam.ac.uk/conts/retrieving.html [or from the Cambridge Crystallographic Data Centre (CCDC), 12 Union Road, Cambridge CB2 1EZ, UK; fax: +44(0)1223-336033; email: deposit@ccdc.cam.ac.uk].

Acknowledgments Authors would like to thank the Hungary-Serbia IPA Cross-border Co-operation Programme (Project No. HUSRB/ 1002/214/133 RECODAC), Provincial Secretariat for Science and Technological Development of Vojvodina (Grant No. 114-451-946/ 2015-03) and Ministry of Education, Science and Technological Development of the Republic of Serbia for financial support (Grant No. 172021). The work of N. Szabó was supported by a PhD Fellowship of the Talentum Fund of Richter Gedeon Plc.

\section{References}

1. Rasmussen MK, Ekstrand B, Zamaratskaia G (2013) Int J Mol Sci 14:17926-17942

2. Vihko P, Herrala A, Härkönen $P$, Isomaa V, Kaija H, Kurkela R, Li Y, Patrikainen L, Pulkka A, Soronen P, Törn S (2005) J Steroid Biochem 93:277-283 
3. Marchais-Oberwinkler S, Henn C, Müller G, Klein T, Negri M, Oster A, Spadaro A, Werth R, Wetzel M, Xu K, Frotscher M, Hartmann RW, Adamski J (2011) J Steroid Biochem Mol Biol 125:66-82

4. Tremblay MR, Lin SX, Poirier D (2001) Steroids 66:821-831

5. Maltais R, Ayan D, Trottier A, Barbeau X, Lagüe P, Bouchard JE, Poirier D (2014) J Med Chem 57:204-222

6. Maltais R, Trottier A, Delhommea A, Barbeau X, Lagüe P, Poirier D (2015) Eur J Med Chem 93:470-480

7. Szabó J, Bacsa I, Wölfling J, Schneider G, Zupkó I, Varga M, Herman BE, Kalmár L, Szécsi M, Mernyák E (2015) J Enzyme Inhib Med Chem. doi:10.3109/14756366.2015.1050008

8. Sam KM, Labrie F, Poirier D (2000) Eur J Med Chem $35: 217-225$

9. Bydal P, Auger S, Poirier D (2004) Steroids 69:325-342

10. Spires TE, Fink BE, Kick EK, You D, Rizzo CA, Takenaka I, Lawrence MR, Ruan Z, Salvati ME, Vite GD, Weinmann R, Attar RM, Gottardis MM, Lorenzi MV (2005) Prostate 65(2):159-170

11. Salvador JAR, Carvalho JFS, Neves MAC, Silvestre SM, Leitão AJ, Silva MMC, Sá e Melo ML (2013) Nat Prod Rep 30:324-374

12. Oklješa A, Jovanović-Šanta S, Klisurić O, Sakač M, Djurendić E, Jakimov D, Aleksić L, Penov Gaši K (2013) J Braz Chem Soc 24(10):1613-1622

13. Sakač MN, Gaković AR, Csanadi JJ, Djurendić EA, Klisurić O, Kojić V, Bogdanović G, Penov Gaši KM (2009) Tetrahedron Lett 50:4107-4109

14. Jovanović-Šanta SS, Andrić S, Andrić N, Bogdanović G, Petrović JA (2011) Med Chem Res 20:1102-1110

15. Penov Gaši KM, Oklješa AM, Petri ET, Ćelić AS, Djurendić EA, Klisurić OR, Csanadi JJ, Batta G, Nikolić AR, Jakimov DS, Sakač MN (2013) MedChemComm 4:317-323

16. Mernyák E, Fiser G, Szabó J, Bodnár B, Schneider G, Kovács I, Ocsovszki I, Zupkó I, Wölfling J (2014) Steroids 89:47-55

17. Mernyák E, Szabó J, Huber J, Schneider G, Minorics R, Bózsity N, Zupkó I, Varga M, Bikádi Z, Hazai E, Wölfling J (2014) Steroids 87:128-136

18. Römer W, Oettel M, Menzenbach B, Droescher P, Schwarz S (1997) Steroids 62:688-694

19. Behl C, Skutella T, Lezoualc'h F, Post A, Widmann M, Newton CJ, Holsboer F (1997) Mol Pharmacol 51:535-541

20. Perez E, Cai ZY, Covey DF, Simpkins JW (2006) Drug Dev Res 66:78-92

21. Ott I, Schmidt K, Kircher B, Schumacher P, Wiglenda T, Gust R (2005) J Med Chem 48:622-629

22. Ekinci D, Sentürk M, Küfrevioglu OI (2011) Expert Opin Ther Pat 21(12):1831-1841

23. Fletcher S, Singh J, Zhang X, Yue P, Page BDG, Sharmeen S, Shahani VM, Zhao W, Schimmer AD, Turkson J, Gunning PT (2009) ChemBioChem 10(12):1959-1964

24. Djurendić EA, Dojčinović-Vujašković SV, Sakač MN, Jovin EDJ, Kojić VV, Bogdanović GM, Klisurić OR, Stanković SM, Lazar DV, Fabian L, Penov-Gaši KM (2010) Struct Chem 21:67-78
25. Djurendić E, Dojčinović-Vujašković S, Sakač M, Ajduković J, Gaković A, Kojić V, Bogdanović G, Klisurić O, Penov-Gaši K (2011) Arkivoc 2:83-102

26. Djurendić E, Savić M, Jovanović-Šanta S, Sakač M, Kojić V, Szécsi M, Oklješa A, Poša M, Penov Gaši K (2014) Acta Period Technol 45:173-189

27. Djurendić E, Klisurić O, Szécsi M, Sakač M, Jovanović-Šanta S, Ignáth I, Kojić V, Oklješa A, Savić M, Penov Gaši K (2014) Struct Chem 25:1747-1758

28. Penov Gaši KM, Djurendić EA, Szécsi M, Gardi J, Csanadi JJ, Klisurić OR, Dojčinović-Vujašković SV, Nikolić AR, Savić MP, Ajduković JJ, Oklješa AM, Kojić VV, Sakač MN, JovanovićŠanta SS (2015) Steroids 94:31-40

29. Penov Gaši K, Djurendić E, Dojčinović Vujašković S, Gaković A, Jovanović-Šanta S, Kojić V, Sakač M (2012) Chem Pap 66(4):284-294

30. Klaunig JE, Kamendulis LM, Hocevar BA (2010) Toxicol Pathol 38:96-109

31. Butenandt A, Strömer I, Westphal V (1932) Z Physiol Chem 208:149-172

32. Jovanović-Šanta S, Petri E, Klisurić O, Szecsi M, Kovačević R, Petrović J (2015) Steroids 97:45-53

33. Skehan P, Storeng R, Scudiero D, Monks A, McMahon J, Vistica D, Warren TJ, Bokesch H, Kenney S, Boyd RM (1990) J Natl Cancer Inst 82:1107-1112

34. Tóth I, Szécsi M, Julesz J, Faredin I (1997) Skin Pharmacol 10(3):160-168

35. Darvas B, Székács A, Fónagy A, Szécsi M, Tóth I (1997) Gen Comp Endocrinol 107(3):450-460

36. Oxford Diffraction CrysAlis CCD and CrysAlis RED (2008) Versions 1.171. Oxford Diffraction Ltd, Abingdon, Oxfordshire, England

37. Sheldrick GM (2008) Acta Crystallogr A 64:112-122

38. Altomare A, Cascarano G, Giacovazzo C, Guagliardi A (1993) J Appl Cryst 26:343-350

39. Bernardinelli G, Flack HD (1985) Acta Cryst A41:500-511

40. Nardelli MJ (1995) Appl Cryst 28:659-662

41. Spek AL (1998) PLATON, a multipurpose crystallographic tool. University of Utrecht, The Netherlands

42. Farrugia LJ (1999) J Appl Cryst 32:876-881

43. Jovanović-Šanta S, Andrić S, Kovačević R, Pejanović V (2000) Collect Czech Chem Commun 65:77-82

44. David-Beabes GL, Overman MJ, Petrofski JA, Campbell PA, de Marzo AM, Nelson WG (2000) Int J Oncol 17:1077-1086

45. Farrugia LJ (1997) J Appl Crystallogr 30:565

46. Cremer D, Pople JA (1975) J Am Chem Soc 97:1354-1358

47. Duax WL, Weeks CM, Rohrer DC (1976) In: Eliel EL, Allinger N (eds) Topics in stereochemistry, vol 2. Wiley, New York, pp 271-283

48. Hanwell MD, Curtis DE, Lonie DC, Vandermeersch T, Zurek E, Hutchison GR (2012) Avogadro: an advanced semantic chemical editor, visualization, and analysis platform. J Cheminform 4:17

49. Macrae CF, Edgington PR, McCabe P, Pidcock E, Shields GP, Taylor R, van der Streek T (2006) J Appl Cryst 39:453-457

50. Clark RC, Reid JS (1995) Acta Cryst A51:887-897 